\title{
The importance of small fire refugia in the central Sierra Nevada, California, USA
}

\author{
Erika M. Blomdahl ${ }^{1, *}$, Crystal A. Kolden ${ }^{2}$, Arjan J. H. Meddens ${ }^{2}$, and James A. Lutz ${ }^{1}$ \\ ${ }^{1}$ Wildland Resources Department, Utah State University, 5230 Old Main Hill, Logan, Utah \\ 84322-5230, USA \\ ${ }^{2}$ College of Natural Resources, University of Idaho, Moscow, ID 83844-1133, USA \\ *Corresponding author: erika.blomdahl@usu.edu
}

\begin{abstract}
Fire refugia - the unburned areas within fire perimeters - are important to the survival of many taxa through fire events and the revegetation of post-fire landscapes. Previous work has shown that species use and benefit from small-scale fire refugia $\left(1 \mathrm{~m}^{2}\right.$ to $\left.1000 \mathrm{~m}^{2}\right)$, but our understanding of where and how fire refugia form is largely limited to the scale of remotely sensed data (i.e., $900 \mathrm{~m}^{2}$ Landsat pixels). To examine the causes and consequences of small fire refugia, we field-mapped all unburned patches $\geq 1 \mathrm{~m}^{2}$ within a contiguous 25.6 ha forest plot that burned at generally low-to-moderate severity in the 2013 Yosemite Rim Fire, California, USA. Within the Yosemite Forest Dynamics Plot (YFDP), there were 685 unburned patches $\geq 1 \mathrm{~m}^{2}$, covering a total unburned area of $12,597 \mathrm{~m}^{2}(4.9 \%)$. Small refugia occurred in all fire severity classifications. Random forest models showed that the proportion of unburned area of $100 \mathrm{~m}^{2}$ grid cells corresponded to pre-fire density and basal area of trees, distance to the nearest stream, and immediate fire mortality, but the relationships were complex and model accuracy was variable. From a pre-fire population of 34,061 total trees $\geq 1 \mathrm{~cm}$ diameter at breast height $(1.37$ $\mathrm{m}$; $\mathrm{DBH})$ within the plot $\left(1,330\right.$ trees $\left.\mathrm{ha}^{-1}\right)$, trees of all five of the most common species and
\end{abstract}


those DBH $<30 \mathrm{~cm}$ had higher immediate survival rates if their boles were wholly or partially within an unburned patch $(P \leq 0.001)$. Trees $1 \mathrm{~cm} \leq$ DBH $<10$ that survived were located closer to the center of the unburned patch than the edge (mean $1.1 \mathrm{~m}$ versus $0.6 \mathrm{~m}$; ANOVA; $P$ $\leq 0.001$ ). Four-year survival rates for trees $1 \mathrm{~cm} \leq \mathrm{DBH}<10 \mathrm{~cm}$ were $58.8 \%$ within small refugia and $2.7 \%$ in burned areas $(P \leq 0.001)$. Species richness and the Shannon Diversity Index (SDI) were associated with unburned quadrats in NMDS ordinations 3 years post-fire. Burn heterogeneity in mixed-conifer forests likely exists at all scales and small refugia contribute to diversity of forest species and structures. Thus, managers may wish to consider scales from $1-\mathrm{m}^{2}$ to the landscape when designing fuel reduction prescriptions. The partial predictability of refugia location suggests that further work may lead to predictive models of refugial presence that have considerable potential to preserve ecological function or human habitation in fire-frequent forests.

\section{Graphical Abstract}

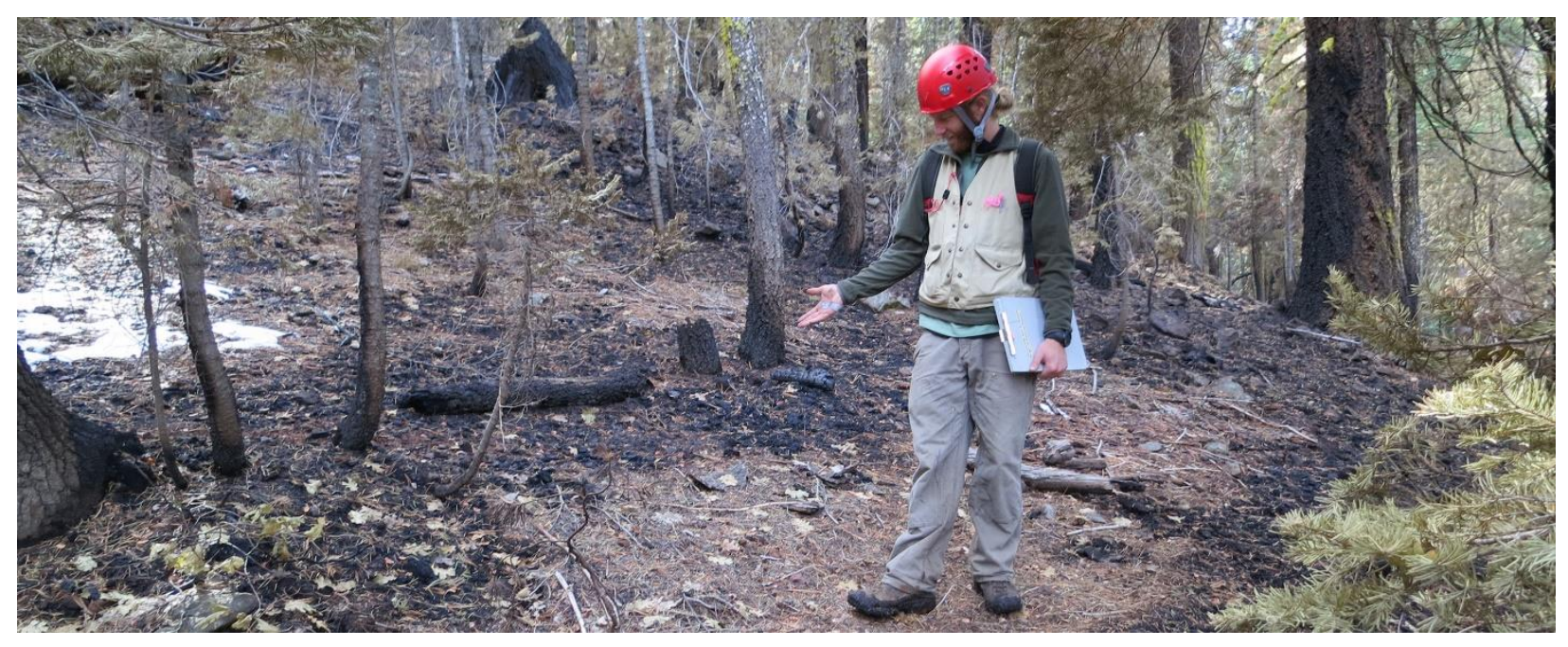

Keywords: fire heterogeneity; fire mortality; fire severity; Smithsonian ForestGEO; Yosemite National Park; Yosemite Forest Dynamics Plot 


\section{Highlights}

- Small $\left(1 \mathrm{~m}^{2} \leq\right.$ area $\left.\leq 900 \mathrm{~m}^{2}\right)$ unburned patches occupied $5 \%$ of the area burned

- Areas with all fire severity classifications contained small unburned patches

- Tree survival was higher when trees were rooted in an unburned patch

- Small tree survival was higher towards the interior of unburned patches

\section{Introduction}

Fire is a principal disturbance process in the dry forests of western North America, and there is widespread evidence that fire activity is increasing (Westerling et al., 2006; Miller and Safford 2012; Dennison et al., 2014). High severity fires and the total area burned have received considerable media attention, depicting an overly simplistic view of fire activity that omits natural variability in fire effects. Within fire perimeters, the distribution of burn severity (i.e., the degree of environmental change following a fire; Key and Benson 2006; Keeley, 2009) is heterogeneous. Fire mosaics consist of myriad burn severities, including areas that experienced little or no burning. A critical outcome of this heterogeneity is the formation of fire refugiaunburned or lightly burned areas in the burned matrix that are functionally unaltered by fire. Fire refugia are important but largely understudied landscape components that preserve ecological function in the immediate aftermath of the fire and may reduce vulnerability to future disturbance (Meddens et al., 2018b). Scientific understanding is particularly limited in the study of small-scale fire refugia $\left(1 \mathrm{~m}^{2}\right.$ to $\left.900 \mathrm{~m}^{2}\right)$, which are known to benefit forest organisms (Robinson et al., 2013), but cannot be reliably detected with most remote-sensing techniques.

Fire refugia influence forest recovery and succession. By buffering lethal temperatures, refugia facilitate the survival and persistence of many taxa during and after a fire event 
(Gasaway and DuBois 1985; Robinson et al., 2013). Remnant vegetation provides immediate post-fire habitat for faunal species, expediting recolonization of burned areas (e.g., Banks et al., 2011). Islands of unburned forest preserve patches of different successional stages (Turner et al., 1997; Kane et al., 2010), thus increasing overall diversity of habitats and forest structure. Patches of surviving mature vegetation act as barriers to erosion and influence immediate successional processes by providing seed sources to repopulate gaps created by the disturbance (Turner et al., 1998). Fire refugia, therefore, are associated with both immediate and long-term benefits to forest organisms.

The study of relatively large fire refugia ( $\geq 1$ ha) has increased in recent decades with the aid of remote sensing (e.g. Meddens et al., 2016, 2018a). Most recent studies have utilized satellite-derived indices based on $30 \mathrm{~m} \times 30 \mathrm{~m}$ Landsat pixels; the resolution of the Landsat instrument is well-suited for analysis of landscape-scale patterns and trends in burn severity and fire size. Fire refugia in this type of study are identified as pixels with an unchanged surface reflectance between pre- and post-fire scenes, which could include several surface conditions (e.g., unburned forest, a sub-canopy burn not reflected in the overstory, or a burn followed by rapid vegetative regrowth; Kolden et al., 2012). Previous work has described the spatial characteristics and environmental predictors of large fire refugia, as well as differences between remnant vegetation and the surrounding forest. Kolden et al., (2012) found that characteristics such as patch size, density, and shape complexity vary with forest type. Other studies have successfully predicted the presence of large fire refugia based on environmental factors such as terrain ruggedness, soil moisture, aspect, and slope (Román-Cuesta et al., 2009; Krawchuk et al.; 2016, Haire et al., 2017). Patches of remnant forest and the surrounding matrix of young forest have exhibited differences in structure, composition, and regeneration (Delong and Kessler 
2000).

Although large fire refugia have been the subject of much interest, small fire refugia have been less studied. Small fire refugia can be characterized by size or lack of change in vertical forest strata (or both). Landsat 30-m reflectance data has been the primary source for refugia classification (e.g. Meddens et al. 2016), but Landsat data can confuse classification of cover and change at the sub-pixel level due to spectral mixing; a fire refugium that dominates a pixel may be classified as "unchanged" while a small refugium surrounded by char and ash may be classified as burned (Kolden and Rogan 2013). Similarly, as spectral indices are predominantly sensitive to changes in forest canopy cover (McCarley et al. 2017), fire refugia in the understory or organic soil/duff layers that are obscured by unchanged forest canopy have not yet been reliably quantified with remote sensing techniques (Kolden et al. 2012), although active remote sensing approaches, such as multitemporal Lidar acquisitions, may provide feasible highresolution alternatives to Landsat for characterizing fire-induced changes in the vertical strata (McCarley et al. 2017). The unburned patches examined here meet both of these criteria, but we characterize them as "small fire refugia" specifically to acknowledge their size of less than 0.09 ha $\left(900 \mathrm{~m}^{2}\right.$; one Landsat pixel) and to contrast them with pixel-based refugia defined by other studies based on an "unchanged" classification from Landsat data.

Small fire refugia have been exclusively studied in the context of a specific study organism, involving ground-based measurements of unburned forest floor, and have been shown to be important mechanisms of survival for both individual species (Brennan et al., 2011; Robinson et al., 2013; Meddens et al., 2018b) and plant communities (Schwilk and Keeley, 2006; Hylander and Johnson, 2010). Rodent populations have been shown to shift to use small unburned drainages, possibly to avoid predation (Banks et al., 2011) or to use post-fire areas with 
higher levels of burn heterogeneity, including unburned areas (Roberts et al., 2008). Other studies have shown that forest-floor-dwelling invertebrates survive fire in unburned patches (Zaitsev et al., 2014) and that unburned microhabitats near residual trees and other vegetation correlate positively with beetle diversity (Gandhi et al., 2001). Tree seedlings and saplings can survive in unburned patches, creating structural diversity that provides more habitat for forest fauna and increases overall forest resilience to disturbances (North et al., 2009).

There is a considerable knowledge gap in our spatial and predictive understanding of small fire refugia. It is unknown how the distribution and formation of small fire refugia compare with studies conducted at a coarser scale, a question relevant to managing forests with fire refugia — of all scales — in mind. It is important, additionally, to understand the relationship between small fire refugia and remotely sensed burn severity. Although, spaceborne remote sensing techniques are unlikely to identify all unburned areas relevant to biota, these methods may help estimate spatial attributes of small refugia in relation to burn severity.

To examine the causes and consequences of small refugia, we field mapped all unburned areas $\geq 1 \mathrm{~m}^{2}$ within a 25.6 ha study area. Our objectives were to: 1 ) characterize the fine-scale spatial distribution of unburned patches, including their sizes, distributions, and correlations with Landsat-derived burn severity; 2) determine the environmental variables predictive of small fire refugia; and 3) compare vegetation in unburned patches and burned areas, including understory community composition and post-fire tree survival. We hypothesized that the spatial distribution of small unburned patches would be aggregated in areas that inhibit fire spread; for example, riparian areas less likely to burn due to the high soil moisture content (Dwire and Kauffman, 2003). Similarly, if the same processes that drive large fire refugia formation also apply to small fire refugia, then abiotic factors such as topography and aspect may be predictive of patch 
presence (Krawchuk et al.; 2016, Haire et al., 2017). We expected that small unburned patches would increase tree survival and have distinct understory communities relative to burned areas.

\section{Methods}

\subsection{Study area}

We conducted this study in the Yosemite Forest Dynamics Plot (YFDP, $37.77^{\circ} \mathrm{N}$, $119.92^{\circ} \mathrm{W}$; Lutz et al., 2012), a 25.6 ha plot in the lower-montane forest zone (1774 $\mathrm{m}$ to 1911 m) of Yosemite National Park (Yosemite; Fig. 1). The climate at the YFDP is Mediterranean, characterized by hot, dry summers and cool, wet winters. Between 1981 and 2010 the annual mean monthly minimum and maximum temperatures were $6{ }^{\circ} \mathrm{C}$ and $16{ }^{\circ} \mathrm{C}$ respectively; annual precipitation was $1070 \mathrm{~mm}$ with most precipitation falling as snow between December and March (Lutz et al., 2010; Prism Climate Group 2017). The YFDP is located in primary Abies concolor-Pinus lambertiana (white fir-sugar pine) forest of the White Fir Superassociation (Keeler-Wolf et al., 2012), with some trees older than 500 years. The five most abundant tree species are (in decreasing abundance): Abies concolor (white fir), Pinus lambertiana (sugar pine), Cornus nuttallii (Pacific dogwood,) Calocedrus decurrens (incense-cedar), and Quercus kelloggii (California black oak). Plant nomenclature follows Flora of North America (1993+).

\subsection{Fire regime}

The fire regime in dry mixed-conifer forests of the Sierra Nevada prior to European settlement was characterized by a mean fire return interval of 11 years (van de Water and Safford, 2011), consistent with an interval of 10 to 13 years found by Scholl and Taylor (2010) approximately $10 \mathrm{~km}$ north of the YFDP. However, the mean fire return interval in the YFDP itself was 29.5 years (Barth et al., 2015), possibly due to the northerly aspect of the plot (Lutz et 
al., 2017). The last widespread fire in the YFDP occurred in 1899, followed by a period of fire exclusion from 1900 to 2012 (Scholl and Taylor 2010, Barth et al., 2015). In Yosemite as a whole, the reintroduction of fire since the 1970s has resulted in mixed- and high-severity fires (van Wagtendonk, 2007; van Wagtendonk and Lutz, 2007; Lutz et al., 2009).

The Rim Fire burned 104,131 ha of mostly forested land in August-September 2013 (Kane et al., 2015a; Stavros et al., 2016), including 32,079 ha within Yosemite. The YFDP was contained entirely within the fire perimeter (Fig. 1). The YFDP burned on September 1st and 2nd in a management-ignited backfire intended to control the spread of the Rim Fire. The fire was started $1 \mathrm{~km}$ away from the YFDP and unmanaged thereafter, with portions of the plot burning in a backing fire at night and the rest burning upslope the following day (Lutz et al., 2017). Unlike portions of the Rim Fire in the Stanislaus National Forest that burned at high severity in plumedominated fire behavior (Lydersen et al., 2014), the YFDP burned at generally low- to moderateseverity (Fig. 1). Pre-fire surface fuel loading was $334.8 \mathrm{Mg} \mathrm{ha}^{-1}$ (Larson et al., 2016), with high values for litter $\left(63.9 \mathrm{Mg} \mathrm{ha}^{-1}\right)$ and duff $\left(188.8 \mathrm{Mg} \mathrm{ha}^{-1}\right)$. Surface fuel consumption was $95 \%$ for litter, 93\% for duff, and 90\% for 1-hour fuels (Larson et al., 2016).

\subsection{Field methods}

The YFDP is a contiguous, rectangular plot comprised of $640,20 \mathrm{~m} \times 20 \mathrm{~m}$ quadrats, within which all trees $\geq 1 \mathrm{~cm}$ DBH were identified, tagged, and mapped in 2009 and 2010 following the methods of the Smithsonian ForestGEO network (Anderson-Teixeira et al., 2015, Lutz, 2015). Each tree was revisited annually between 2011 and 2017 and its status tracked (e.g., live or dead). In 2010 all shrub species $\geq 2 \mathrm{~m}^{2}$ at $40 \%$ cover were identified and mapped using the methods of Lutz et al. (2014). In June 2014 (eight months post-fire), we mapped unburned patches $\geq 1 \mathrm{~m}^{2}$ in the YFDP. Unburned patches were defined by an intact litter and duff layer (i.e. 
canopy conditions were not evaluated in patch delineation). We mapped the unburned patches as polygons following the methods of North et al. (2002), by traversing each quadrat to identify patches. We used ocular estimation to delineate patch vertices in relation to features on field maps (e.g., trees and quadrat grid corners; Figs. S1 and S2). The unburned patch edges were measured using meter tapes, and the datasheets included a representation of a 1-m grid to increase mapping accuracy. Field technicians recorded spatial references to nearby features which were individually verified during digitization (ArcMap 10.3 georeferencing toolbar; Fig. S1). The position of nearby trees was recorded as outside, intersecting, or within an unburned patch.

We established 63, 1- $\mathrm{m}^{2}$ square subplots on a defined grid, 54 of which were burned (>95\% surface fuel consumption). We measured understory vegetation percent cover by species, seedling abundance, in the early growing season (May, June) and after the growing season (August-November) in 2015 through 2017. In order to compare vegetation between burned and unburned areas, in 2016 we installed 40 additional 1- $\mathrm{m}^{2}$ subplots within unburned patches that ranged in size from $16 \mathrm{~m}^{2}$ to $40 \mathrm{~m}^{2}$. In 2016, we measured litter cover and litter and duff depth in the center of each of the four sides of the $1031-\mathrm{m}^{2}$ subplots; the mean of these measurements was used in analysis.

\subsection{Ancillary data}

To calculate burn severity of the Rim Fire, we used Landsat 8/OLI Level 1T surface reflectance pre-fire (July 14, 2013) and post-fire (July 1, 2014) scenes (path 43 row 34) downloaded from the Earth Resources Observation and Science (EROS) Center Science Processing Architecture (ESPA) web portal. We selected the scene pair after examining all available scenes from the growing seasons of 2013 and 2014 for optimal sun angle, phenology, 
and low cloud cover (Key, 2006). We calculated the differenced normalized burn ratio (dNBR) according to Key and Benson (2006). We calculated the dNBR offset (following Meddens et al., 2016) from 780 pixels of unburned forest of the same type located approximately $2 \mathrm{~km}$ south of the YFDP. Categorical burn severity classification was based on dNBR thresholds from Miller and Thode (2007): unchanged, <41; low, 41-176; moderate, 177-366; high, $\geq 367$. There were 260 contiguous Landsat pixels completely within the boundaries of the YFDP and 336 Landsat pixels that intersected at least a portion of the area of the YFDP.

\subsection{Patch summary statistics}

We calculated patch metrics (patch size, patch density, and nearest neighbor) for the total area occupied by each dNBR burn severity category (unchanged, low, moderate, high), and for the entire plot. To calculate distance to nearest patch neighbor the unburned polygons were rasterized using the raster package version 2.6-7 (Hijmans, 2016) in R version 3.4.3 (R Core Team, 2017). The raster cell size that maintained the same total of unburned polygon units was 0.25-m. The nearest patch neighbor was determined as Euclidean distance from the cell center of the focal patch to the cell center of the neighboring patch.

\subsection{Random forest modeling of the unburned fraction}

We used a random forest model (randomForest package version 4.6-12; Liaw and Wiener, 2002) to determine the environmental variables most predictive of unburned patch presence and proportion within contiguous $10 \mathrm{~m} \times 10 \mathrm{~m}$ grid cells $(n=2723)$. All variables were calculated at the scale of the 10-m grid, which was oriented with the 2013 USGS $1 / 3$ arc second (10 m) digital elevation model (DEM). We initially set up the response as the proportion unburned within a $10 \mathrm{~m} \times 10 \mathrm{~m}$ cell, however, the response was heavily weighted with zero values as the majority of the plot surface burned in the fire $(>95 \%)$. We therefore used a zero- 
inflated model approach involving two steps: 1) a model with a binary response variable indicating unburned patch presence/absence, and 2) a model consisting of the non-zero observations with a continuous response variable. At the first step we assessed accuracy metrics (listed in Table 3) to determine if unburned patch presence could be distinguished from burned areas. Based on the prediction accuracy we justified proceeding to the second step, in which we assessed the variables predictive of the proportion unburned. The final random forest regression model was developed using 500 classification trees.

The predictor variables (Table 1, Table S1) were a combination of abiotic and biotic factors hypothesized to influence fire behavior based on previous studies at larger spatial scales (Kane et al., 2013, 2014, 2015b). We calculated the topographic position index (TPI), terrain ruggedness index (TRI), roughness, and slope using the terrain function in the raster package (Hijmans, 2016; Wilson et al., 2007). We calculated insolation using the solar radiation toolset in ArcGIS version 10.3 (ESRI 2011). Distance to water was the minimum Euclidean distance from each grid cell center to the nearest vernal stream course. Shrub cover was assessed (total cover, and separated by guild) using polygons and guild classifications from Lutz et al. (2017). Mortality-based metrics were defined based on pre-fire live trees that died in the first year following the fire. We first included all predictor variables (Fig. S3), and then developed a final model with the ten variables with highest importance by iteratively removing variables of lowest importance (Fig. S4).

\subsection{Tree mortality}

To analyze the effect of unburned patches on tree survival, we calculated mortality rates in burned and unburned areas by species and diameter class. Trees were considered to be in an unburned patch if they were completely within the unburned patch or if their boles intersected 
the perimeter of a patch. We tested for significance $(\alpha=0.05)$ using $\chi^{2}$ tests under the null hypothesis of equal proportion of mortality in burned and unburned areas and used a Bonferroni correction to account for multiple tests. We assessed the relationship of immediate post-fire tree mortality and tree location relative to unburned patch edge. We analyzed trees in unburned patches and trees within burned areas for both burned and unburned trees. We used ANOVA $(\alpha=0.05)$ to test the response of distance to patch edge and the two predictors, diameter class and post-fire status (live, dead). We calculated the distances between features using the gDistance function in the rgeos package version 0.3-26 (Bivand et al., 2017). We used logistic regression to predict post-fire status and validated model accuracy using ten-fold cross-validation.

\subsection{Understory vegetation}

We used non-metric multidimensional scaling (NMDS) to compare understory plant communities in burned and unburned $1-\mathrm{m}^{2}$ quadrats in the YFDP. The community matrix consisted of percent cover data of the species occurring in greater than $5 \%$ of the quadrats, with each species relativized by the column total. The variables in the environmental matrix (Table S1) were measured while the community data were collected $(2016,2017)$, except for percent burned (2015) and litter depth (2016 only). We used the litter depth data in both 2016 and 2017

ordinations under the assumption changes in litter depth between these years was slight. To build the ordinations we used the metaMDS function in R (vegan package version 2.4-6; Oksanen et al., 2013), which performed a double Wisconsin standardization and square root transformation on the community matrix. The final solutions were assembled in two-dimensions (up to threedimensions were considered) using the Bray-Curtis dissimilarity index, with 100 minimum and 500 maximum random starts. Our results display the species centroids with the 5 largest correlation coefficients labeled. To examine the correlation between environmental variables and 
measures of species diversity, we used the env.fit function in R (Oksanen et al., 2013) to plot the significant vectors $(\alpha=0.05)$ on to the ordination space.

\section{Results}

\subsection{Unburned patch metrics}

In the YFDP (25.6 ha), there were 685 unburned patches $\geq 1 \mathrm{~m}^{2}$, with a total unburned area of 12,597 $\mathrm{m}^{2}$ (4.9\%; Table 2). Mean unburned patch size was $18.4 \mathrm{~m}^{2}$ (SD: $49.4 \mathrm{~m}^{2}$, min: 1 $\mathrm{m}^{2}$, max: $895.6 \mathrm{~m}^{2}$ ). Patch density varied with burn severity class (Table 2 ), with the highest concentration of actual unburned patches in Landsat pixels calculated as unchanged by dNBR (48.8 patches ha $\left.^{-1}\right)$. Unburned patch densities were similar in low- and moderate-severity pixels (27.5 and 26.0 patches ha $^{-1}$, respectively), with the lowest number of unburned patches in highseverity pixels (11.1 patches $\left.\mathrm{ha}^{-1}\right)$. The average nearest neighbor distance between unburned patches was $4.3 \mathrm{~m}$ for the whole plot, with the shortest nearest neighbor distances occurring between Landsat unchanged pixels (mean: $1.6 \mathrm{~m}$ ) and the longest nearest neighbor distances occurring between high-severity pixels (mean: $6.2 \mathrm{~m}$; Table 2). The actual unburned area within individual dNBR pixels had a weak negative relationship with dNBR burn severity, whether considered categorically (Table 2) or continuously (Fig. 2).

\subsection{Random forest model}

The presence-absence random forest model correctly predicted observed values $73.6 \%$ of the time. The model correctly predicted unburned patch absence (i.e. completely burned areas) $88.7 \%$ of the time, compared to $46.3 \%$ for unburned patch presence. Of the rows incorrectly classified by the model (25.6\%), $72.2 \%$ of these errors were unburned presence observations incorrectly predicted as absence. 
The presence-only random forest model with a continuous response of proportion unburned had a mean difference between predicted and observed values of 0.63 (Table 3 ). The predictors that contributed the most to increase in mean square error (MSE), a measure of variable importance to model accuracy, were (in order of importance): distance to stream (m), mortality basal area $\left(\mathrm{m}^{2} \mathrm{ha}^{-1}\right)$, basal area $\left(\mathrm{m}^{2} \mathrm{ha}^{-1}\right)$, density $\left(\right.$ stems ha $\left.{ }^{-1}\right)$, mortality density (stems $\mathrm{ha}^{-1}$ ) and the Topographic Position Index (Fig. 3). The mean of the predicted values plotted against the observed values demonstrated the model was best at predicting unburned proportion from $0 \%$ to $35 \%$, and less accurate for predicting larger patches (Fig. 3F).

\subsection{Understory tree mortality}

Total pre-fire tree density in the unburned areas of the plot was 871 stems ha ${ }^{-1}$ compared to 1,359 stems $^{-1}$ in burned areas. Immediate tree mortality rate was $26.7 \%$ within unburned patches and $72.5 \%$ in burned areas (Table 4). The greatest difference in tree mortality was in the $1 \mathrm{~cm} \leq \mathrm{DBH}<10 \mathrm{~cm}$ diameter class, with mortality in burned and unburned areas of $90.5 \%$ and $30.6 \%$ respectively ( $\chi^{2}$ tests, $P<0.001$ ). There was no mortality for trees $\geq 30 \mathrm{~cm} \mathrm{DBH}$ located within unburned patches, compared to $11.5 \%$ mortality for trees $30 \mathrm{~cm} \leq \mathrm{DBH}<60 \mathrm{~cm}$ in burned areas (Table 4). Cornus nutallii was the tree species with the highest proportion of its population located within unburned patches (15.8\%), while Pinus lambertiana had the lowest proportion represented (1.5\%). Differences in mortality rates between burned and unburned areas by species tended to correspond to the proportion located within unburned patches.

Four years after the fire, trees had markedly higher survival rates in unburned patches for all species and diameter classes $\leq 60 \mathrm{~cm} \mathrm{DBH}$ (Fig. 4). The greatest difference in survival was for trees $1 \mathrm{~cm} \leq \mathrm{DBH}<10 \mathrm{~cm}$, where $58.8 \%$ survived in unburned patches and $2.7 \%$ survived in burned areas $\left(\chi^{2}\right.$ tests, $\left.P<0.001\right)$. Survival rates for trees $60 \mathrm{~cm} \leq \mathrm{DBH}<90 \mathrm{~cm}$ did not differ 
between unburned and burned areas $\left(66.7 \%\right.$ and $62.9 \% ; \chi^{2}$ tests, $\left.P=0.901\right)$.

Trees in unburned patches survived at higher rates when they were farther from the patch edge (mean: $1.1 \mathrm{~m}$, min: $0 \mathrm{~m}$, max: $5.7 \mathrm{~m}$ ), while trees in unburned patches that died were closer to the patch edge (mean: $0.6 \mathrm{~m}$, min: $0 \mathrm{~m}$, max: $2.9 \mathrm{~m}$ ). The position within unburned patches of trees $1 \mathrm{~cm} \leq \mathrm{DBH}<10 \mathrm{~cm}$ that survived was farther from the edge than trees that died (ANOVA, $P<0.001$ ), indicating that buffering from radiant and convective heat was critical to survival of small-diameter trees. Distance to patch edge did not predict survival for trees $10 \mathrm{~cm} \leq$ $\mathrm{DBH}<30 \mathrm{~cm}$ (ANOVA, $P=0.204$ ) or larger. Trees in burned areas that survived were closer to unburned patches (mean: $8.6 \mathrm{~m}$, min: $0 \mathrm{~m}$, max: $44.3 \mathrm{~m}$ ) than trees that died (mean: $11.0 \mathrm{~m}$, min: $0 \mathrm{~m}$, max: $47.6 \mathrm{~m}$ ), with significant differences (ANOVA, $P<0.05$ ) for all diameter classes except for trees $\geq 90 \mathrm{~cm} \mathrm{DBH}($ ANOVA, $P=0.643$ ).

\subsection{Understory vegetation}

The NMDS ordinations showed a modest separation between burned and unburned quadrats for both years, suggesting these areas contain distinct understory communities (Fig. 5). The final solutions had a stress of 0.18 for both 2016 and 2017. Six vectors had significant associations $(\alpha=0.05)$ with the ordination configuration: percent burned, litter depth, seedling abundance, percent cover, species richness, and the Shannon Diversity Index (SDI). Most notably, species richness and SDI were associated with unburned quadrats (richness: $r_{2016}=0.10$, $r_{2017}=0.11$; SDI: $\left.r_{2016}=0.09, r_{2017}=0.10\right)$, indicating that small refugia include plant communities with a greater number of species and a more even distribution than those of burned areas. In addition to the diversity indices, percent cover and litter depth were correlated with unburned areas (cover: $r_{2016}=0.10, r_{2017}=0.04$; litter depth: $\left.r_{2016}=0.09, r_{2017}=0.10\right)$, suggesting either that small fire refugia are places with high vegetative cover, or that recolonization of burned areas 3 
to 4 years after fire does not match the cover observed in unburned areas. Seedling abundance was negatively correlated with unburned plots in $2017(r=0.06)$, likely because the litter layer acts as a barrier for the anchoring of seedling roots. Species composition in the burned plots was more similar to that of the unburned plots in 2017 relative to 2016, suggesting that understory recolonization four years post-fire homogenizes these two areas.

Despite community differences visible in the NMDS ordinations, mean quadrat summary metrics for all understory species (including rare species) did not differ significantly in burned and unburned areas (Table S2). Mean cover in unburned quadrats was 21.8\% (SD: 22.2\%, min: 0\%, max: $150.8 \%$ ); compared to $13.1 \%$ in burned quadrats (SD: $22.4 \%$, min: $0 \%$, max: 104.5\%; Table S2; $P=0.121)$. Average seedling abundance was $6 \mathrm{~m}^{-2}$ in burned quadrats and $2 \mathrm{~m}^{-2}$ in unburned quadrats $(P=0.180)$. Species richness in unburned quadrats was $6.4 \mathrm{~m}^{-2}\left(\mathrm{~min}: 0 \mathrm{~m}^{-2}\right.$, max: $15 \mathrm{~m}^{-2}$ ) and $3.2 \mathrm{~m}^{-2}$ in burned quadrats (min: $0 \mathrm{~m}^{-2}$, max: $12 \mathrm{~m}^{-2}$ ), but the differences were not significant $(P=0.266)$.

\section{Discussion}

\subsection{Characteristics of small fire refugia}

Small fire refugia $\left(1 \mathrm{~m}^{2}\right.$ to $\left.900 \mathrm{~m}^{2}\right)$ were abundant throughout the study area in this lowto moderate-severity fire. The fire traversed the entire plot, with the exception of approximately $5 \%$ of the forest surface. Refugia occurred in all landscape positions and dNBR burn severity classes; it is important to note, however, that pixels classified as unchanged or high severity were very limited in the study area.

Although small fire refugia were present within pixels of all dNBR severities, they were fewer and farther apart with increasing dNBR. We posit that this pattern is influenced by soil, fuel continuity, and litter moisture (Wohlgemuth et al., 2006). Environments that tend to burn at 
moderate or high severity, such as steep, rocky areas, may exhibit reduced fuel continuity because of the rocky matrix and low productivity (Kolden et al., 2017). Low fuel continuity could lead some areas to remain unburned despite high flame heights associated with steep slopes. In low burn severity environments, such as drainages and riparian areas, high litter moisture and cold air pooling inhibit fire spread, possibly leading to more abundant and less dispersed unburned patches (Dwire and Kauffman, 2003).

Individual unburned patch area showed no relationship with dNBR as a continuous metric (Fig. 2), suggesting that burn severity may be entirely unrelated to unburned patch size and that many conditions associated with both high and low dNBR can give rise to small unburned patches. Stochasticity in fire behavior, such as a change in wind direction or relative humidity, may give rise to small skips in the burning of surface fuels (irrespective of burn severity). However, refugial patches were closer together in low severity pixels and farther apart in areas of high burn severity. While burn severity may not control patch size, the results suggest that burn severity potentially influences patch density and proportion of area unburned, consistent with prior studies (Kolden et al. 2015).

\subsection{Limitations of $d N B R$}

Our results highlight a consequence of the limited spatial resolution of Landsat-derived dNBR — small fire refugia cannot be reliably detected. Pixels with an unchanged surface reflectance at $30 \mathrm{~m} \times 30 \mathrm{~m}$ grain occupied $0.9 \%$ of the YFDP, much lower than the $4.9 \%$ unburned surface layer determined by field observations. This is not surprising - dNBR values primarily exhibit overstory changes because differenced Landsat scenes cannot detect surface burning when masked by the canopy (Kolden et al., 2012). 
The spatial resolution of dNBR is an important consideration in the interpretation of our results regarding unburned patch distribution in relation to fire severity classifications. Landsatderived pixels represent an average of spectral changes over a $900 \mathrm{~m}^{2}$ area, thus $\mathrm{dNBR}$ values may not accurately reflect overstory conditions most proximate to field-mapped unburned patches. Areas classified as moderate burn severity, for example, could be largely unburned but contain a high severity patch in a fraction of the pixel.

\subsection{Predicting small refugia}

Inaccuracies in our presence-absence random forest model may be due to the presence of different types of small fire refugia in our dataset. Fire refugia include those that are persistent or ephemeral (sensu Meddens et al., 2018b). Predictive models might reach a high level of accuracy

for persistent refugia that are controlled primarily by their landscape position or surrounding vegetation, but it may be difficult to model ephemeral refugia, where the locations are controlled by the vagaries of fire progression, in anything other than a probabilistic sense. The relative proportion of persistent and ephemeral refugia on the landscape remains an open area of research.

In a separate analysis of the cells our presence-absence model could accurately predict, we found that the proportion of likely persistent refugia (sensu Meddens et al., 2018b) is considerable, and can be modeled with physiologically plausible predictors (i.e., distance to streams, proximate tree density and basal area, proximate tree mortality, and topographic position). A distance of $11 \mathrm{~m}$ from the nearest stream maximized the unburned proportion, and interestingly, the unburned proportion increased slightly from stream distances of $100 \mathrm{~m}$ to 300 $\mathrm{m}$, suggesting that the distribution of refugia responds to multiple factors (Fig. 3A). The unburned proportion was highest in areas with the lowest mortality by basal area, a measure of 
burn severity (Fig. 3B). Low basal area, which is often associated with low productivity areas, was also correlated with high unburned proportion (Fig. 3C). Refugia occurred in areas of both high and low stem densities (Fig. 3D), likely a reflection of the high stem densities of riparian species (i.e., Cornus sericea and Cornus nuttallii) and the low fuel continuity associated with low stem densities (Fig. 3D). Topographic Position Index had less explanatory power, but indicated unburned proportion was slightly higher in concave lower slopes and convex upper slopes (Fig. 3E).

Data limitations likely contributed to model inaccuracies in predicting small fire refugia presence. Following the abstraction of the fire behavior triangle (fuels, weather, topography), our set of predictors was incomplete. Topography was approximated through DEM-derived indices and their predictive ability was less than vegetation-related predictors. Our measures of fuel loading and consumption were indirect, as we used proxies known to contribute to the litter and duff layer (e.g., nearby tree density and basal area) or to represent fire intensity (e.g., local tree mortality). We had no measurements of fine-scale fire weather (but see Lutz et al., 2017). There was also a scale problem, wherein our predictive data did not necessarily match the spatial scale of the refugia we delineated, which influences model predictive power (Birch et al., 2015).

\subsection{Impact of small refugia on tree mortality and survival}

Despite our definition of refugia as entirely unburned at the surface, tree mortality still occurred in unburned areas. Our field measurements of unburned patches considered only the forest floor and root crowns when classifying an area as either burned or unburned. Radiant and convective heat from the flames, however, was often lethal for sub-canopy foliage, and many trees located within unburned patches experienced crown scorch despite having an intact litter layer. Overall, however, small refugia were a significant source of tree survival for all species 
and diameter classes $<60 \mathrm{~cm}$ DBH and these higher survival rates persisted for at least four years. The deciduous species Quercus kelloggii and Cornus nuttallii were more susceptible to bole scorch mortality due to their thinner bark, and consequently these species experienced the greatest increases in survival when located in small refugia. Trees positioned deeper within unburned patches had higher survival rates, likely due to heat buffering resulting in sub-lethal fire heating (i.e., Smith et al., 2016b, 2017).

Small-diameter trees disproportionally benefited from the heat buffering effects of small refugia. After a century of fire suppression, which resulted in increased tree densities and high ground fuel accumulations, even low- to moderate-severity surface fires can be fatal to most subcanopy trees while larger and older trees survive (Larson et al. 2015). Small refugia may be important determinants of the trees that eventually recruit into the canopy; trees $<10 \mathrm{~cm} \mathrm{DBH}$ that escape fire by virtue of being in refugia may be large enough to survive the next fire, even if that subsequent fire burns near them (Becker and Lutz 2016). By preserving a population of advanced regeneration, small refugia may be a means through which forests maintain structural diversity (Lutz et al. 2018).

\subsection{Understory vegetation in burned and unburned areas}

Small fire refugia appear to host more diverse understory plant communities relative to burned areas 3 and 4 years post-fire (Fig. 5). Burned areas were dominated by colonizing species or in some cases, lacked any vegetative regrowth, while unburned areas likely maintained prefire species composition. We draw two conclusions from the higher understory plant diversity found in unburned areas. First, places where small fire refugia form may host different and/or more diverse understory communities than areas that burned. Alternatively, the same understory communities may have been prevalent throughout burned and unburned areas, and those 
surviving in small fire refugia represent starting points for post-fire recolonization of burned areas. In either case, refugial areas may be a mechanism by which forests maintain biodiversity across periods of disturbance.

\subsection{Scale}

The fine-scale resolution and spatial extent of this dataset allows us to address whether spatial patterns of fire refugia are maintained across scales (i.e., Lutz et al., 2018a). Previous work has examined fire refugia primarily at the landscape scale, for which the smallest unit of measure is a $900 \mathrm{~m}^{2}$ Landsat pixel. Kolden et al., (2012) and Kolden et al., (2015) reported the average unburned proportion in Yosemite National Park at 20\% to 25\%, much higher than the 5\% unburned area found in this study. Moreover, the fire in the YFDP had a substantial lowseverity component (44.8\%); based on the results of Kolden et al. (2012) we would expect a higher proportion of unburned area following lower severity fire. Several conditions could explain these incongruities. First, these results suggest that—at least for low- to moderateseverity fire-landscape-scale factors that give rise to large fire refugia (e.g. aspect, topography, burn history) may not apply at fine scales. Second, the methods associated with measuring small vs. large fire refugia are based on different definitions of unburned refugia. Whereas we delineated unburned patches based on the presence of an intact litter and duff layer, unchanged dNBR pixels could represent several ground conditions, including unburned forest; an undetectable low-severity burn; or regrown vegetation with an identical spectral signal to that of the pre-fire scene (Kolden et al., 2012). Given the possible surface conditions that large fire refugia could represent, it is not surprising that the unburned proportion differs between large and small scales.

\section{Conclusions and Management Implications}


The portion of the Rim Fire that was burned by the management-ignited backfire was broadly consistent in terms of mean severity and pattern with recent fires in Yosemite that have been allowed to burn (van Wagtendonk and Lutz 2007, Lutz et al. 2011, Thode et al. 2011) suggesting that the density of small refugia found here $\left(26.7 \mathrm{ha}^{-1}\right)$ is representative of characteristic fire behavior, at least on north-facing slopes within the Abies concolor superassociation where Landsat-derived fire severity was low to moderate. In contrast, many prescribed fires ignited to reduce fuels would be expected to leave far fewer small refugia because a specific operational objective is to burn essentially the entire forest floor. Frequentfire forests of the Sierra Nevada are renowned for their vascular plant species diversity and their structural heterogeneity (Lutz et al. 2013, 2018b), which is at least partially due to heterogeneity in fire effects and behavior (Kane et al., 2015a). We show that the small fire refugia observed after a low- to moderate-severity fire were associated with more diverse understory plant communities and may contribute to structural diversity through increased survival of smalldiameter trees relative to burned areas. To preserve these outcomes, managers conducting prescribed fires as fuel reduction treatments may wish to consider allowing some unburned patches to remain within treatment areas. Uniformly burning all surface area within a treatment block is uncharacteristic of the contemporary, unmanaged fire regime in these forests, and may stall elements of post-fire development. Fire heterogeneity in Sierra Nevada forests is likely present at all spatial scales, and therefore managers may wish to consider all scales from $1-\mathrm{m}^{2}$ to the landscape.

Better knowledge of refugia may also help create fire-resilient communities (sensu Smith et al., 2016a). The predictability of refugia location (albeit with limited skill) suggests that further research may lead to predictive models of refugial presence that have considerable 
potential to preserve ecological function or human habitation in frequent-fire forests. If characteristics associated with refugia can be better identified, these characteristics (to the extent that they are biotic in nature) can be modified by planting tree species that are associated with less intense fire behavior (e.g., Fechner and Barrows, 1976) or thinning to help protect areas of ecological or anthropogenic importance.

\section{Acknowledgements}

We thank W. George, S. Hiebert, M. Jones, and G. Kenagy for their hard work in mapping the unburned patches and $\mathrm{K}$. Becker for understory vegetation and seedling data. This research was funded by grants from the Department of the Interior Northwest Climate Science Center through a Cooperative Agreement G14AP00177 from the United States Geological Survey, the National Park Service (Awards P14AC00122 and P14AC00197) and the Utah Agricultural Extension Station, Utah State University, which has designated this as journal paper \#9069. C.A.K and A.J.H.M. acknowledge support from Joint Fire Science Program (JFSP, Cooperative Agreement: L16AC00202). We thank Yosemite National Park for logistical assistance and the Yosemite Forest Dynamics Plot field crews, individually acknowledged at http://yfdp.org. This work was performed under National Park Service research permits YOSE2014-SCI-0005, YOSE-2015-SCI-0014, YOSE-2016-SCI-0006, and YOSE-2017-SCI-0009 for study YOSE-0051.

\section{References}

Anderson-Teixeira, K. J., S. J. Davies, A. C. Bennett, E. B. Gonzalez-Akre, H. C. MullerLandau, S. Joseph Wright, K. Abu Salim, A. M. Almeyda Zambrano, A. Alonso, J. L. Baltzer, Y. Basset, N. A. Bourg, E. N. Broadbent, W. Y. Brockelman, S. Bunyavejchewin, D. F. R. P. Burslem, N. Butt, M. Cao, D. Cardenas, G. B. Chuyong, K. Clay, S. Cordell, H. S. Dattaraja, X. Deng, M. Detto, X. Du, A. Duque, D. L. Erikson, C. E. N. Ewango, G. A. Fischer, C. 
Fletcher, R. B. Foster, C. P. Giardina, G. S. Gilbert, N. Gunatilleke, S. Gunatilleke, Z. Hao, W. W. Hargrove, T. B. Hart, B. C. H. Hau, F. He, F. M. Hoffman, R. W. Howe, S. P. Hubbell, F. M. Inman-Narahari, P. A. Jansen, M. Jiang, D. J. Johnson, M. Kanzaki, A. R. Kassim, D. Kenfack, S. Kibet, M. F. Kinnaird, L. Korte, K. Kral, J. Kumar, A. J. Larson, Y. Li, X. Li, S. Liu, S. K. Y. Lum, J. A. Lutz, K. Ma, D. M. Maddalena, J. R. Makana, Y. Malhi, T. Marthews, R. Mat Serudin, S. M. Mcmahon, W. J. McShea, H. R. Memiaghe, X. Mi, T. Mizuno, M. Morecroft, J. A. Myers, V. Novotny, A. A. de Oliveira, P. S. Ong, D. A. Orwig, R. Ostertag, J. den Ouden, G. G. Parker, R. P. Phillips, L. Sack, M. N. Sainge, W. Sang, K. Sringernyuang, R. Sukumar, I. F. Sun, W. Sungpalee, H. S. Suresh, S. Tan, S. C. Thomas, D. W. Thomas, J. Thompson, B. L. Turner, M. Uriarte, R. Valencia, M. I. Vallejo, A. Vicentini, T. Vrška, X. Wang, X. Wang, G. Weiblen, A. Wolf, H. Xu, S. Yap, and J. Zimmerman. 2015. CTFS-ForestGEO: A worldwide network monitoring forests in an era of global change. Global Change Biology 21: 528-549.

Banks, S. C., M. Dujardin, L. McBurney, D. Blair, M. Barker, and D. B. Lindenmayer. 2011. Starting points for small mammal population recovery after wildfire: Recolonisation or residual populations? Oikos 120: 26-37.

Barth, M. A. F., A. J. Larson, and J. A. Lutz. 2015. A forest reconstruction model to assess changes to Sierra Nevada mixed-conifer forest during the fire suppression era. Forest Ecology and Management 354: 104-118.

Becker, K., and J. A. Lutz. 2016. Low-severity fire fails to reverse overstory compositional change in montane forests of the Sierra Nevada. Ecosphere 7(12): e01484.

Birch, D. S., P. Morgan, C. A. Kolden, J. T. Abatzoglou, G. K. Dillon, A. T. Hudak, and A. M. S. Smith. 2015. Vegetation, topography and daily weather influenced burn severity in central Idaho and western Montana forests. Ecosphere 6: art17.

Bivand, R., C. Rundel, E. Pebesma, R. Stuetz, and K. O. Hufthammer. 2017. Interface to geometry engine - open source ('GEOS'). Version 0.3-26. http://cran.rproject.org/package=rgeos. Downloaded 23 March 2018.

Brennan, K. E. C., M. L. Moir, and R. S. Wittkuhn. 2011. Fire refugia: The mechanism governing animal survivorship within a highly flammable plant. Austral Ecology 36:131-141.

Delong, S. C., and W. B. Kessler. 2000. Ecological characteristics of mature forest remnants left by wildfire. Forest Ecology and Management 131: 93-106.

Dennison, P. E., S. C. Brewer, J. D. Arnold, and M. A. Moritz. 2014. Large wildfire trends in the western United States, 1984-2011. Geophysical Research Letters 41: 2928-2933.

Dwire, K. A., and J. B. Kauffman. 2003. Fire and riparian ecosystems in landscapes of the western USA. Forest Ecology and Management 178(1-2): 61-74.

ESRI. 2011. ArcGIS Desktop: Release 10.3. Environmental Systems Research Institute, Redlands, California, USA.

Fechner, G. H., and J. S. Barrows. 1976. Aspen stands as wildfire fuel breaks. Eisenhower Consortium Bulletin 4. Department of Forestry and Wood Science, College of Natural Resources, Colorado State University, Fort Collins, Colorado, USA.

Gandhi, K. J. K., J. R. Spence, D. W. Langor, and L. E. Morgantini. 2001. Fire residuals as habitat reserves for epigaeic beetles (Coleoptera: Carabidae and Staphylinidae). Biological Conservation 102: 131-141.

Gasaway, W. C., and S. D. DuBois. 1985. Initial response of moose, Alces alces, to a wildfire in Interior Alaska. Canadian Field-Naturalist 99: 135-140. 
Haire, S., J. Coop, and C. Miller. 2017. Characterizing spatial neighborhoods of refugia following large fires in northern New Mexico USA. Land 6: 19.

Hijmans, R. J. 2016. raster: Geographic Data Analysis and Modeling. R package version 2.6-7. https://CRAN.R-project.org/package=raster. Downloaded 23 March 2018.

Hylander, K., and S. Johnson. 2010. In situ survival of forest bryophytes in small-scale refugia after an intense forest fire. Journal of Vegetation Science 21: 1099-1109.

Kane, V. R., J. D. Bakker, R. J. McGaughey, J. A. Lutz, R. F. Gersonde, and J. F. Franklin. 2010. Examining conifer canopy structural complexity across forest ages and elevations with LiDAR data. Canadian Journal of Forest Research 40: 774-787.

Kane, V. R., C. A. Cansler, N. A. Povak, J. T. Kane, R. J. McGaughey, J. A. Lutz, D. J. Churchill, and M. P. North. 2015a. Mixed severity fire effects within the Rim fire: Relative importance of local climate, fire weather, topography, and forest structure. Forest Ecology and Management 358: 62-79.

Kane, V. R., J. A. Lutz, C. Alina Cansler, N. A. Povak, D. J. Churchill, D. F. Smith, J. T. Kane, and M. P. North. 2015b. Water balance and topography predict fire and forest structure patterns. Forest Ecology and Management 338: 1-13.

Kane, V. R., J. A. Lutz, S. L. Roberts, D. F. Smith, R. J. McGaughey, N. A. Povak, and M. L. Brooks. 2013. Landscape-scale effects of fire severity on mixed-conifer and red fir forest structure in Yosemite National Park. Forest Ecology and Management 287: 17-31.

Kane, V. R., M. P. North, J. A. Lutz, D. J. Churchill, S. L. Roberts, D. F. Smith, R. J. McGaughey, J. T. Kane, and M. L. Brooks. 2014. Assessing fire effects on forest spatial structure using a fusion of landsat and airborne LiDAR data in Yosemite national park. Remote Sensing of Environment 151: 89-101.

Keeler-Wolf, T., P. E. Moore, E. T. Reyes, J. M. Menke, D. N. Johnson, and D. L. Karavidas. 2012. Yosemite National Park Vegetation Classification and Mapping Project Report. Natural Resource Report NPS/YOSE/NRTR-2012/598. National Park Service, Fort Collins, Colorado.

Keeley, J. E. 2009. Fire intensity, fire severity and burn severity: A brief review and suggested usage. International Journal of Wildland Fire 18: 116-126.

Key, C. H. 2006. Ecological and sampling constraints on defining landscape fire severity. Fire Ecology 2: 34-59.

Key, C. H., and N. C. Benson. 2006. Landscape assessment: Sampling and analysis methods. General Technical Report RMRS-GTR-164-CD. USDA Forest Service, Rocky Mountain Research Station, Fort Collins, Colorado.

Kolden, C. A., J. A. Lutz, C. H. Key, J. T. Kane, and J. W. van Wagtendonk. 2012. Mapped versus actual burned area within wildfire perimeters: characterizing the unburned. Forest Ecology and Management 286: 38-47.

Kolden, C.A. and J. Rogan. 2013. Mapping wildfire burn severity in the Arctic tundra from downsampled MODIS data. Arctic, antarctic, and alpine research 45(1): 64-76.

Kolden, C. A., J. T. Abatzoglou, J. A. Lutz, C. A. Cansler, J. T. Kane, J. W. van Wagtendonk, and C. H. Key. 2015. Climate contributors to forest mosaics: ecological persistence following wildfire. Northwest Science 89(3): 219-238.

Kolden, C. A., T. M. Bleeker, A. M. S. Smith, H. M. Poulos, and A. E. Camp. 2017. Fire effects on historical wildfire refugia in contemporary wildfires. Forests 8: f8100400.

Krawchuk, M. A., S. L. Haire, J. D. Coop, M.-A. Parisien, E. Whitman, G. W. Chong, and C. Miller. 2016. Topographic and fire weather controls of fire refugia in forested ecosystems of northwestern North America. Ecosphere 7(12): e01632. 
Larson, A. J., C. A. Cansler, S. G. Cowdery, S. Hiebert, T. J. Furniss, M. E. Swanson, and J. A. Lutz. 2016. Post-fire morel (Morchella) mushroom abundance, spatial structure, and harvest sustainability. Forest Ecology and Management 377: 16-25.

Larson, A. J., J. A. Lutz, D. C. Donato, J. A. Freund, M. E. Swanson, J. HilleRisLambers, D. G. Sprugel, and J. F. Franklin. 2015. Spatial aspects of tree mortality strongly differ between young and old-growth forests. Ecology 96(11): 2855-2861.

Liaw, A., and M. Wiener. 2002. Classification and Regression by randomForest. R News 2:1822.

Lutz, J. A., J. W. Van Wagtendonk, A. E. Thode, J. D. Miller, and J. F. Franklin. 2009. Climate, lightning ignitions, and fire severity in Yosemite National Park, California, USA. International Journal of Wildland Fire 18(7): 765-774.

Lutz, J. A., J. W. van Wagtendonk, and J. F. Franklin. 2010. Climatic water deficit, tree species ranges, and climate change in Yosemite National Park. Journal of Biogeography 37: 936-950.

Lutz, J. A., C. H. Key, C. A. Kolden, J. T. Kane, and J. W. van Wagtendonk. 2011. Fire frequency, area burned, and severity: A quantitative approach to defining a normal fire year. Fire Ecology 7(2): 51-65.

Lutz, J. A., A. J. Larson, M. E. Swanson, and J. A. Freund. 2013. Ecological importance of large-diameter trees in a temperate mixed-conifer forest. PLoS ONE 7(5): e36131.

Lutz, J. A., K. A. Schwindt, T. J. Furniss, J. A. Freund, M. E. Swanson, K. I. Hogan, G. E. Kenagy, and A. J. Larson. 2014. Community composition and allometry of Leucothoe davisiae, Cornus sericea, and Chrysolepis sempervirens. Canadian Journal of Forestry Research 44(6): 677-683.

Lutz, J. A. 2015. The evolution of long-term data for forestry: large temperate research plots in an era of global change. Northwest Science 89:255-269.

Lutz, J. A., T. J. Furniss, S. J. Germain, K. M. L. Becker, E. M. Blomdahl, S. A. Jeronimo, C. A. Cansler, J. A. Freund, M. E. Swanson, and A. J. Larson. 2017. Shrub communities, spatial patterns, and shrub-mediated tree mortality following reintroduced fire in Yosemite National Park, California, USA. Fire Ecology 13(1): 104-126.

Lutz, J. A., T. J. Furniss †, D. J. Johnson, S. J. Davies, D. Allen, A. Alonso, K. AndersonTeixeira, A. Andrade, J. Baltzer, K. M. L. Becker†, E. M. Blomdahl†, N. A. Bourg, S. Bunyavejchewin, D. F. R. P. Burslem, C. A. Cansler, K. Cao, M. Cao, D. Cárdenas, L-W. Chang, K-J Chao, W-C. Chao, J-M. Chiang, C. Chu, G. B. Chuyong, K. Clay, R. Condit, S. Cordell, H. S. Dattaraja, A. Duque, C. E. N. Ewango, G. A. Fisher, C. Fletcher, J. A. Fruend, C. Giardina, S. J. Germain $\dagger$, G. S. Gilbert, Z. Hao, T. Hart, B. C. H. Hau, F. He, A. Hector, R. W. Howe, C-F. Hsieh, Y-H. Hu, S. P. Hubbell, F. M. Inman-Narahari, A. Itoh, D. Janik, A. R. Kassim, D. Kenfack, L. Korte, K. Král, A. J. Larson, Y-D. Li, Y. Lin, S. Liu, S. Lum, K. Ma, J-R. Makana, Y. Malhi, S. M. McMahon, W. J. McShea, H. R. Memiaghe, X. Mi, M. Morecroft, P. M. Musili, J. A. Myers, V. Novotny, A. de Oliveira, P. Ong, D. A. Orwig, R. Osterag, G. G. Parker, R. Patankar, R. P. Phillips, G. Reynolds, L. Sack, G-Z. M. Song, S-H. Su, R. Sukumar, I-F. Sun, H. S. Suresh, M. E. Swanson, S. Tan, D. W. Thomas, J. Thompson, M. Uriarte, R. Valencia, A. Vicentini, T. Vrška, X. Wang, G. D. Weiblen, A. Wolf, S-H. Wu, H. Xu, T. Yamakura, S. Yap, and J. K. Zimmerman. 2018. Global importance of largediameter trees. Global Ecology and Biogeography 27(7): 849-864.

Lydersen, J. M., M. P. North, and B. M. Collins. 2014. Severity of an uncharacteristically large wildfire, the Rim Fire, in forests with relatively restored frequent fire regimes. Forest Ecology and Management 328: 326-334. 
McCarley, T. R., C. A. Kolden, N. M. Vaillant, A. T. Hudak, A. M. S. Smith, B. M. Wing, B. S. Kellogg, and J. Kreitler. 2017. Multi-temporal LiDAR and Landsat quantification of fireinduced changes to forest structure. Remote Sensing of Environment 191:419-432.

Meddens, A. J. H., C. A. Kolden, and J. A. Lutz. 2016. Detecting unburned areas within wildfire perimeters using Landsat and ancillary data across the northwestern United States. Remote Sensing of Environment 186:275-285.

Meddens, A. J. H., C. A. Kolden, J. A. Lutz, J. T. Abatzoglou, and A. T. Hudak. 2018 a. Spatiotemporal patterns of unburned areas within fire perimeters in the northwestern United States from 1984 to 2014. Ecosphere 9(2): e02029.

Meddens, A. J. H., C. A. Kolden, J. A. Lutz, A. M. S. Smith, C. A. Cansler, J. T. Abatzoglou, G. W. Meigs, W. M. Downing, and M. A. Krawchuk. 2018b (in press). Fire refugia: What are they and why do they matter for global change? BioScience.

Miller, J. D., and A. E. Thode. 2007. Quantifying burn severity in a heterogeneous landscape with a relative version of the delta Normalized Burn Ration (dNBR). Remote Sensing of Environment 109: 66-80.

Miller, J. D., and H. Safford. 2012. Trends in wildfire severity: 1984 to 2010 in the Sierra Nevada, Modoc Plateau, and southern Cascades, California, USA. Fire Ecology 8: 41-57.

North, M., B. Oakley, J. Chen, H. Erickson, A. Gray, A. Izzo, D. Johnson, S. Ma, J. Marra, M. Meyer, K. Purcell, T. Rambo, D. Rizzo, B. Roath, and T. Schowalter. 2002. Vegetation and Ecological Characteristics of Mixed Conifer and Red Fir Forests at The Teakettle Experimental Forest. General Technical Report PSW-GTR-186. Page General Technical Report PSW-GTR-186. U.S. Department of Agriculture, Forest Service, Pacific Southwest Research Station, Davis, California, USA.

North, M., P. Stine, K. O. Hara, W. Zielinski, and S. Stephens. 2009. An Ecosystem Management Strategy for Sierran Mixed- Conifer Forests. PSW-GTR-220. U.S. Department of Agriculture, Forest Service, Pacific Southwest Research Station, Davis, California, USA.

Oksanen, J., F. G. Blanchet, R. Kindt, P. Legendre, P. R. Minchin, R. B. O’Hara, G. L. Simpson, P. Solymos, M. H. H. Stevens, and H. Wagner. 2013. Vegan: community ecology package. Version 2.4-6. http://cran.r-project.org/package=vegan. Downloaded 23 March 2018.

Prism Climate Group. 2017. Climatological normals, 1981-2010. The PRISM Group, Oregon State University, Oregon, USA. http://prism.oregonstate.edu.

R Core Team. 2017. R: A language and environment for statistical computing. Version 3.4.3. R Core Team, R Foundation for Statistical Computing, Vienna, Austria.

Roberts, S. L., J. W. van Wagtendonk, D. A. Kelt, A. K. Miles, and J. A. Lutz. 2008. Modeling the effects of fire severity and spatial complexity on small mammals in Yosemite National Park, California. Fire Ecology 4(2): 83-104.

Robinson, N. M., S. W. J. Leonard, E. G. Ritchie, M. Bassett, E. K. Chia, S. Buckingham, H. Gibb, A. F. Bennett, and M. F. Clarke. 2013. Refuges for fauna in fire-prone landscapes: Their ecological function and importance. Journal of Applied Ecology 50: 1321-1329.

Román-Cuesta, R. M., M. Gracia, and J. Retana. 2009. Factors influencing the formation of unburned forest islands within the perimeter of a large forest fire. Forest Ecology and Management 258: 71-80.

Scholl, A. E., and A. H. Taylor. 2010. Fire regimes, forest change, and self-organization in an old-growth mixed-conifer forest, Yosemite National Park, USA. Ecological Applications 20: $362-380$. 
Schwilk, D. W., and J. E. Keeley. 2006. The role of fire refugia in the distribution of Pinus sabiniana (Pinaceae) in the southern Sierra Nevada. Madroño 53(4): 364-372.

Smith, A. M. S., C. A. Kolden, T. B. Paveglio, M. A. Cochrane, D. M. J. S. Bowman, M. A. Moritz, A. D. Kliskey, L. Alessa, A. T. Hudak, C. M. Hoffman, J. A. Lutz, L. P. Queen, S. J. Goetz, P. E. Higuera, L. Boschetti, M. Flannigan, K. M. Yedinak, A. C. Watts, E. K. Strand, J. W. Van Wagtendonk, J. W. Anderson, B. J. Stocks, and J. T. Abatzoglou. 2016a. The science of firescapes: achieving fire-resilient communities. BioScience 66: 130-146.

Smith, A. M. S., A. M. Sparks, C. A. Kolden, J. T. Abatzoglou, A. F. Talhelm, D. M. Johnson, L. Boschetti, J. A. Lutz, K. G. Apostol, K. M. Yedinak, W. T. Tinkham, and R. J. Kremens. 2016b. Towards a new paradigm in fire severity research using dose-response experiments. International Journal of Wildland Fire 25: 158-166.

Smith, A. M. S., A. F. Talhelm, D. M. Johnson, A. M. Sparks, C. A. Kolden, K. M. Yedinak, K. G. Apostol, W. T. Tinkham, J. T. Abatzoglou, J. A. Lutz, A. S. Davis, K. S. Pregitzer, H. D. Adams, and R. L. Kremens. 2017. Effects of fire radiative energy density dose on Pinus contorta and Larix occidentalis seedling physiology and mortality. International Journal of Wildland Fire 26: 82-94.

Stavros, E. N., Z. Tane, V. R. Kane, S. Veraverbeke, R. J. McGaughey, J. A. Lutz, and C. Ramirez. 2016. Unprecedented remote sensing data over the King and Rim Megafires in the Sierra Nevada Mountains of California. Ecology 97(11): 3244.

Thode, A. E., J. W. van Wagtendonk, J. D. Miller, and J. F. Quinn. 2011. Quantifying the fire regime distributions for severity in Yosemite National Park, California, USA. International Journal of Wildland Fire 20: 223-239.

Tobler, W. 1969. Geographical filters and their inverses. Geographical Analysis1: 234-253.

Turner, M. G., W. L. Baker, C. J. Peterson, and R. K. Peet. 1998. Factors Influencing Succession: Lessons from Large, Infrequent Natural Disturbances. Ecosystems 1: 511-523.

Turner, M. G., W. H. Romme, R. H. Gardner, and W. W. Hargrove. 1997. Effects of fire size and pattern on early succession in Yellowstone National Park. Ecological Monographs 67: 411433.

van Wagtendonk, J. W. 2007. The history and evolution of wildland fire use. Fire Ecology 3(2): 3-17.

van Wagtendonk, J. W., and J. A. Lutz. 2007. Fire regime attributes of wildland fires in Yosemite National Park, USA. Fire Ecology 3(2): 34-52.

van de Water, K. M., and H. D. Safford. 2011. A summary of fire frequency estimates for California vegetation before Euro-American settlement. Fire Ecology 7(3): 26-58.

Westerling, A. L., H. G. Hidalgo, D. R. Cayan, and T. W. Swetnam. 2006. Warming and earlier spring increase western U.S. forest wildfire activity. Science 313: 940-3.

Wilson, M. F. J., B. O’Connell, C. Brown, J. C. Guinan, and A. J. Grehan. 2007. Multiscale terrain analysis of multibeam bathymetry data for habitat mapping on the continental slope. Marine Geodesy 30(1-2): 3-35.

Wohlgemuth, P. M., K. Hubbert, and M. J. Arbaugh. 2006. Fire and Physical Environment Interactions. Pages 75-93 in N. G. Sugihara, J. W. van Wagtendonk, K. E. Shaffer, J. FitesKaufman, A. E. Thode, editors. Fire in California's Ecosystems. University of California Press, Berkeley, California.

Zaitsev, A. S., K. B. Gongalsky, T. Persson, and J. Bengtsson. 2014. Connectivity of litter islands remaining after a fire and unburnt forest determines the recovery of soil fauna. Applied Soil Ecology 83: 101-108. 
Tables and Figures

Table 1

3 Model predictors used to predict the presence and proportion of unburned areas. The predictor variables were derived from the US Geological Survey $1 / 3$ arc-second $(10 \mathrm{~m})$ digital elevation model (DEM), the National Hydrological Database (NHD), Landsat 8, and the Yosemite Forest Dynamics Plot (YFDP) tree and mortality data. The satellite-derived burn severity index used was the differenced normalized burn ratio (dNBR). Shrub cover was separated by species into three guilds: montane, generalist, and riparian according to the classifications of Lutz et al., (2017). The descriptions for the terrain variables (roughness, topographic position, and topographic ruggedness) are based on descriptions from Hijmans 2016.

\begin{tabular}{|c|c|c|c|}
\hline Variable Name & Variable description & Units & Source \\
\hline \multicolumn{4}{|l|}{ Abiotic factors } \\
\hline Distance to water & $\begin{array}{l}\text { Minimum distance from unburned patch } \\
\text { centroid to water source }\end{array}$ & Meters & NHD \\
\hline Roughness & $\begin{array}{l}\text { The difference between the range of a cell and } \\
\text { its surrounding cells }\end{array}$ & $\begin{array}{l}\text { Relative } \\
\text { index }\end{array}$ & DEM \\
\hline Slope & Steepness of landscape & Degrees & DEM \\
\hline Solar incidence & $\begin{array}{l}\text { Total amount of solar energy hitting a pixel } \\
\text { surface on the day of the fire }\end{array}$ & $\mathrm{W} / \mathrm{m}^{2}$ & DEM \\
\hline Topographic position & $\begin{array}{l}\text { The difference between a focal cell and the } \\
\text { mean of the surrounding cells }\end{array}$ & $\begin{array}{l}\text { Relative } \\
\text { index }\end{array}$ & DEM \\
\hline Topographic ruggedness & $\begin{array}{l}\text { The mean of the absolute differences of a } \\
\text { focal cell and the surrounding cells }\end{array}$ & $\begin{array}{l}\text { Relative } \\
\text { index }\end{array}$ & DEM \\
\hline \multicolumn{4}{|l|}{ Biotic factors } \\
\hline Basal area & Area occupied by tree stems & $\mathrm{m}^{2} \mathrm{ha}^{-1}$ & YFDP \\
\hline dNBR & $\begin{array}{l}\text { Satellite-derived index of environmental } \\
\text { change caused by fire }\end{array}$ & $\begin{array}{l}\text { Relative } \\
\text { index }\end{array}$ & Landsat \\
\hline Mortality basal area & $\begin{array}{l}\text { Proportion of basal area that experienced } \\
\text { immediate fire-related mortality }\end{array}$ & Percent & YFDP \\
\hline Mortality tree density & $\begin{array}{l}\text { Proportion of live trees that experienced } \\
\text { immediate fire-related mortality }\end{array}$ & Percent & YFDP \\
\hline Shrub cover & Cover occupied by shrub species (all guilds) & $\mathrm{m}^{2}$ & $\begin{array}{l}\text { Lutz et } \\
\text { al. } 2017\end{array}$ \\
\hline Shrub cover by guild & $\begin{array}{l}\text { Shrub cover separated into guilds: generalist, } \\
\text { montane, and riparian }\end{array}$ & $\mathrm{m}^{2}$ & $\begin{array}{l}\text { Lutz et } \\
\text { al. } 2017\end{array}$ \\
\hline Tree density & Number of tree stems & stems ha ${ }^{-1}$ & YFDP \\
\hline Tree density ( 1 to $10 \mathrm{~cm})$ & Number of tree stems $1 \mathrm{~cm} \leq \mathrm{DBH}<10 \mathrm{~cm}$ & stems ha ${ }^{-1}$ & YFDP \\
\hline Tree density $(10$ to $30 \mathrm{~cm})$ & Number of tree stems $10 \mathrm{~cm} \leq \mathrm{DBH}<30 \mathrm{~cm}$ & stems ha ${ }^{-1}$ & YFDP \\
\hline Tree density $(30$ to $60 \mathrm{~cm})$ & Number of tree stems $30 \mathrm{~cm} \leq \mathrm{DBH}<60 \mathrm{~cm}$ & stems ha ${ }^{-1}$ & YFDP \\
\hline Tree density $(60$ to $90 \mathrm{~cm})$ & Number of tree stems $60 \mathrm{~cm} \leq \mathrm{DBH}<90 \mathrm{~cm}$ & stems ha ${ }^{-1}$ & YFDP \\
\hline Tree density $(\geq 90 \mathrm{~cm})$ & Number of tree stems $\mathrm{DBH} \geq 90 \mathrm{~cm}$ & stems ha ${ }^{-1}$ & YFDP \\
\hline
\end{tabular}




\section{Table 2}

13 Spatial attributes of small fire refugia in the Yosemite Forest Dynamics Plot (YFDP),

14 categorized by differenced Normalized Burn Ratio (dNBR) severity classes. Burn severity

15 classifications follow Miller and Thode (2007): unchanged, < 41; low, 41-176; moderate, 176-

16366 ; high, $\geq 367$. The nearest neighbor metric is the mean of the nearest neighbor distances for

17 each burn severity class.

\begin{tabular}{lrrrrrrrr}
\hline $\begin{array}{c}\text { Burn } \\
\text { severity } \\
(\mathrm{dNBR})\end{array}$ & $\begin{array}{r}\text { Unburned } \\
\text { area } \\
\left(\mathrm{m}^{2}\right)\end{array}$ & $\begin{array}{r}\text { Prop. } \\
\text { YFDP }\end{array}$ & $\begin{array}{r}\text { Prop. Unburned } \\
\text { unburned }\end{array}$ & $\begin{array}{r}\text { Density } \\
\text { patches } \\
(\%)\end{array}$ & $\begin{array}{r}\text { Mean } \\
(n)\end{array}$ & $\begin{array}{r}\text { Patch } \\
\left.\mathrm{ha}^{-1}\right)\end{array}$ & $\begin{array}{r}\text { size } \\
\left(\mathrm{m}^{2}\right)\end{array}$ & $\begin{array}{r}\text { Searest } \\
\left(\mathrm{m}^{2}\right)\end{array}$ \\
\hline Unchanged & 339.1 & 0.9 & 15.0 & 11 & 48.8 & 30.8 & 39.0 & $\begin{array}{r}\text { neighbor } \\
(\mathrm{m})\end{array}$ \\
Low & $6,756.3$ & 44.8 & 5.9 & 316 & 27.5 & 21.4 & 61.0 & 4.6 \\
Moderate & $5,419.9$ & 53.2 & 4.0 & 355 & 26.0 & 15.3 & 36.7 & 4.3 \\
High & 81.3 & 1.1 & 3.0 & 3 & 11.1 & 27.1 & 41.1 & 6.2 \\
\hline Total YFDP & $12,596.6$ & 100.0 & 4.9 & 685 & 26.7 & 18.4 & 49.5 & 4.3 \\
\hline
\end{tabular}


Table 3

20 Accuracy statistics for the two random forest classification models: out of bag (OOB) error rate

21 (a measure of overall percent incorrectly classified), sensitivity (the true positive rate), specificity

22 (the true negative rate), and area under curve (AUC; a threshold-independent metric that

23 combines sensitivity and specificity). Accuracy measures for the random forest regression model

24 predicting the non-zero unburned proportion: Variation explained (\%), mean difference between

25 predicted and observed values, root mean square error (RMSE), mean absolute error (MAE), and

26 the difference between RMSE and MAE.

\begin{tabular}{rrrr}
\hline Presence-absence model with binary response \\
\hline OOB Error & Sensitivity & Specificity & AUC \\
25.6 & 0.89 & 0.46 & 0.76 \\
\hline Presence-only model with continuous response \\
\hline Var. & Mean & RMSE & MAE \\
explained & difference & & \\
30.4 & 0.63 & 17.3 & 13.1 \\
\hline
\end{tabular}


Table 4

29 Abundances and immediate (2014) mortality rates of all trees in the Yosemite Forest Dynamics

30 Plot during the Rim fire (2013). Trees were categorized based on whether their bole was wholly

31 or partially in an unburned patch $\geq 1 \mathrm{~m}^{2}$ (unburned) or not (burned). Mortality rates for trees

32 within unburned patches were lower for the five most abundant species and the two smallest

33 diameter classes $\left(\chi^{2}\right.$ tests with a Bonferroni correction, modified $\alpha=0.01 ; P<0.001$ for all).

34 Significant differences indicated in bold.

\begin{tabular}{|c|c|c|c|c|c|c|}
\hline & \multicolumn{3}{|c|}{ Pre-fire live tree abundance } & \multicolumn{3}{|c|}{ Post-fire mortality rates } \\
\hline & $\begin{array}{r}\text { Entire } \\
\text { plot } \\
(n) \\
\end{array}$ & $\begin{array}{r}\text { Unburned } \\
\text { areas } \\
(n) \\
\end{array}$ & $\begin{array}{r}\text { Burned } \\
\text { areas } \\
(n) \\
\end{array}$ & $\begin{array}{r}\text { Entire } \\
\text { plot } \\
(\%) \\
\end{array}$ & $\begin{array}{r}\text { Unburned } \\
\text { areas } \\
(\%) \\
\end{array}$ & $\begin{array}{r}\text { Burned } \\
\text { areas } \\
(\%) \\
\end{array}$ \\
\hline \multicolumn{7}{|l|}{ Species } \\
\hline Abies concolor & 23999 & 473 & 23526 & 72.5 & 29.2 & 73.3 \\
\hline Pinus lambertiana & 4616 & 67 & 4549 & 63.7 & 35.8 & 64.1 \\
\hline Cornus nuttallii & 2701 & 428 & 2273 & 77.1 & 23.4 & 87.2 \\
\hline Calocedrus decurrens & 1635 & 49 & 1586 & 63.9 & 24.5 & 65.1 \\
\hline Quercus kelloggii & 1110 & 63 & 1047 & 63.2 & 14.3 & 66.1 \\
\hline \multicolumn{7}{|l|}{ Diameter class } \\
\hline $1 \mathrm{~cm} \leq \mathrm{DBH}<10 \mathrm{~cm}$ & 21226 & 890 & 20336 & 90.5 & 30.6 & 93.1 \\
\hline $10 \mathrm{~cm} \leq \mathrm{DBH}<30 \mathrm{~cm}$ & 9415 & 195 & 9220 & 50.9 & 10.8 & 51.8 \\
\hline $30 \mathrm{~cm} \leq \mathrm{DBH}<60 \mathrm{~cm}$ & 2293 & 10 & 2283 & 11.5 & 0.0 & 11.5 \\
\hline $60 \mathrm{~cm} \leq \mathrm{DBH}<90 \mathrm{~cm}$ & 690 & 3 & 687 & 3.3 & 0.0 & 3.3 \\
\hline $\mathrm{DBH} \geq 90 \mathrm{~cm}$ & 621 & 0 & 621 & 4.0 & $N A$ & 4.0 \\
\hline Total & 34061 & 1080 & 32981 & 71.0 & 26.7 & 72.5 \\
\hline
\end{tabular}





37 Fig. 1. Location of the Yosemite Forest Dynamics Plot (C) within Yosemite National Park (B), California (A). The footprint of the Rim Fire of 2013 had large contiguous portions that burned at high-severity (B), but within the YFDP, the Rim Fire burned at low- to moderate-severity (C). There were 260 Landsat pixels completely within the YFDP and 336 pixels that intersected the YFDP (C). Small fire refugia $\left(\geq 1 \mathrm{~m}^{2}\right)$ were present in all burn severity classes (black shading within C). Differenced Normalized Burn Ratio (dNBR) categorical classifications follow Miller and Thode (2007): unchanged, < 41; low, 41-176; moderate, 176-366; high, $\geq 367$. 

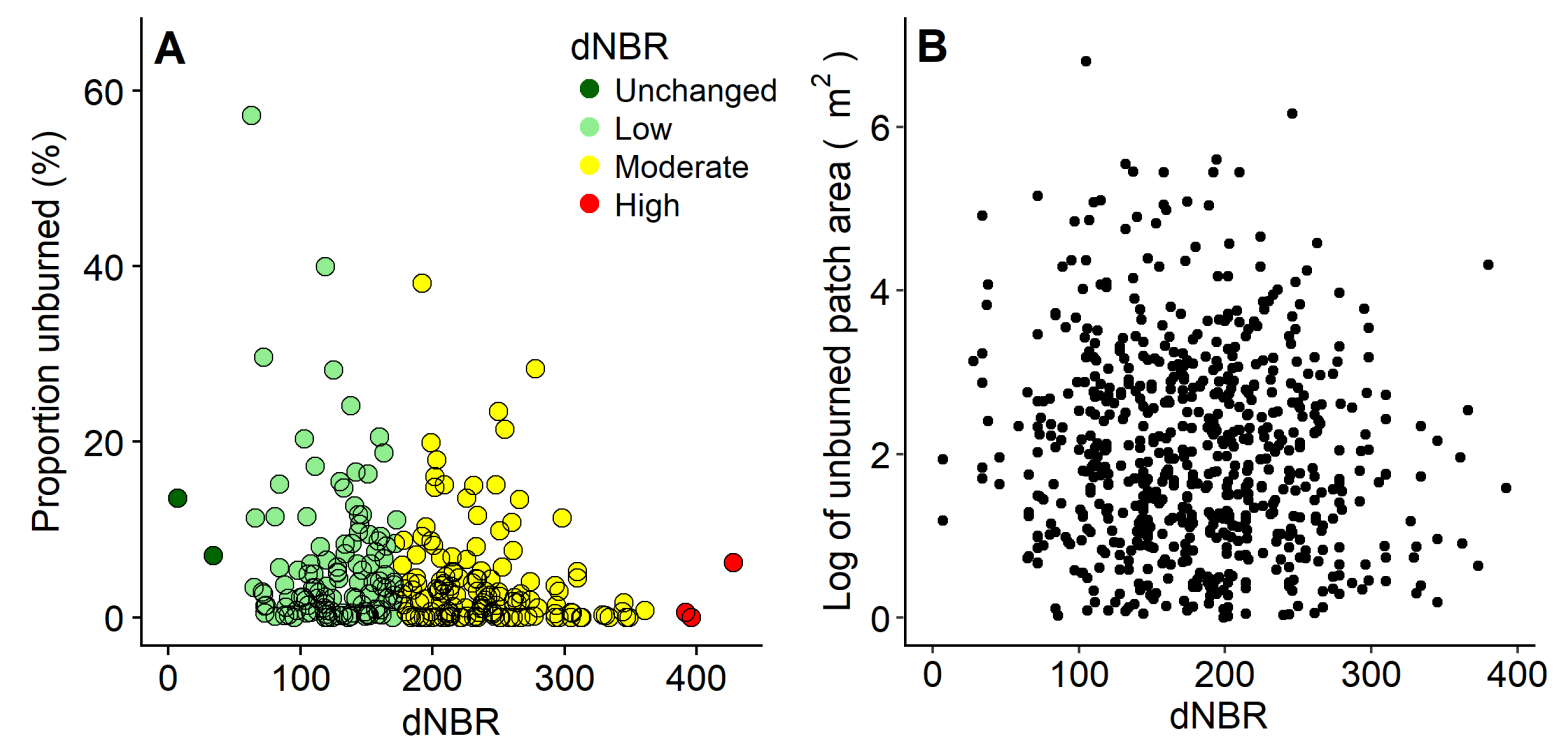

Fig. 2. Differenced Normalized Burn Ratio (dNBR) pixel values for the Yosemite Forest Dynamics Plot and the proportion of each pixel's ground surface that was observed as unburned (A). There was no relationship between the log-transformed unburned patch area and the associated dNBR values (B), suggesting factors other than satellite-derived burn severity control the size of small refugia. The dNBR severity classifications follow Miller and Thode (2007): unchanged, <41; low, 41-176; moderate, 176-366; high, $\geq 367$. 

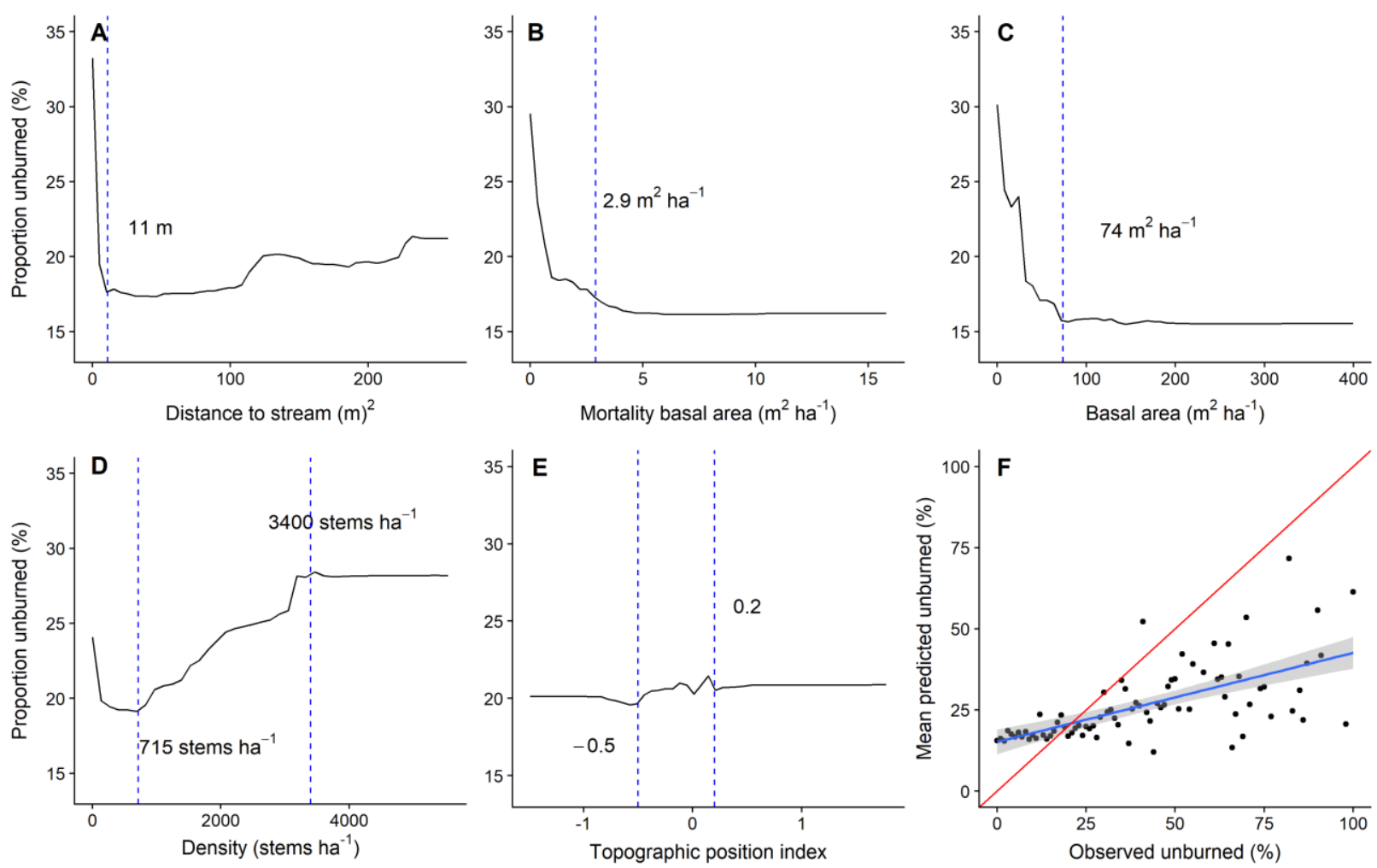

Fig. 3. Partial dependence plots of random forest model variables, listed in order of variable importance: distance to stream (A), local tree mortality as measured by basal area (B), pre-fire

54 tree basal area (C), pre-fire tree density (D), and topographic position index (E). Panel F depicts a measure of model accuracy in aggregate: the mean of the predicted dependence variable plotted against the observed response in bins (rounded to the nearest whole number). The blue line represents the smoothed linear model of the mean predicted versus observed values with a $95 \%$ confidence interval. The red line is a linear visual aid to contrast with the slope of the plotted values. In all plots, dashed vertical lines indicate inflection points. 

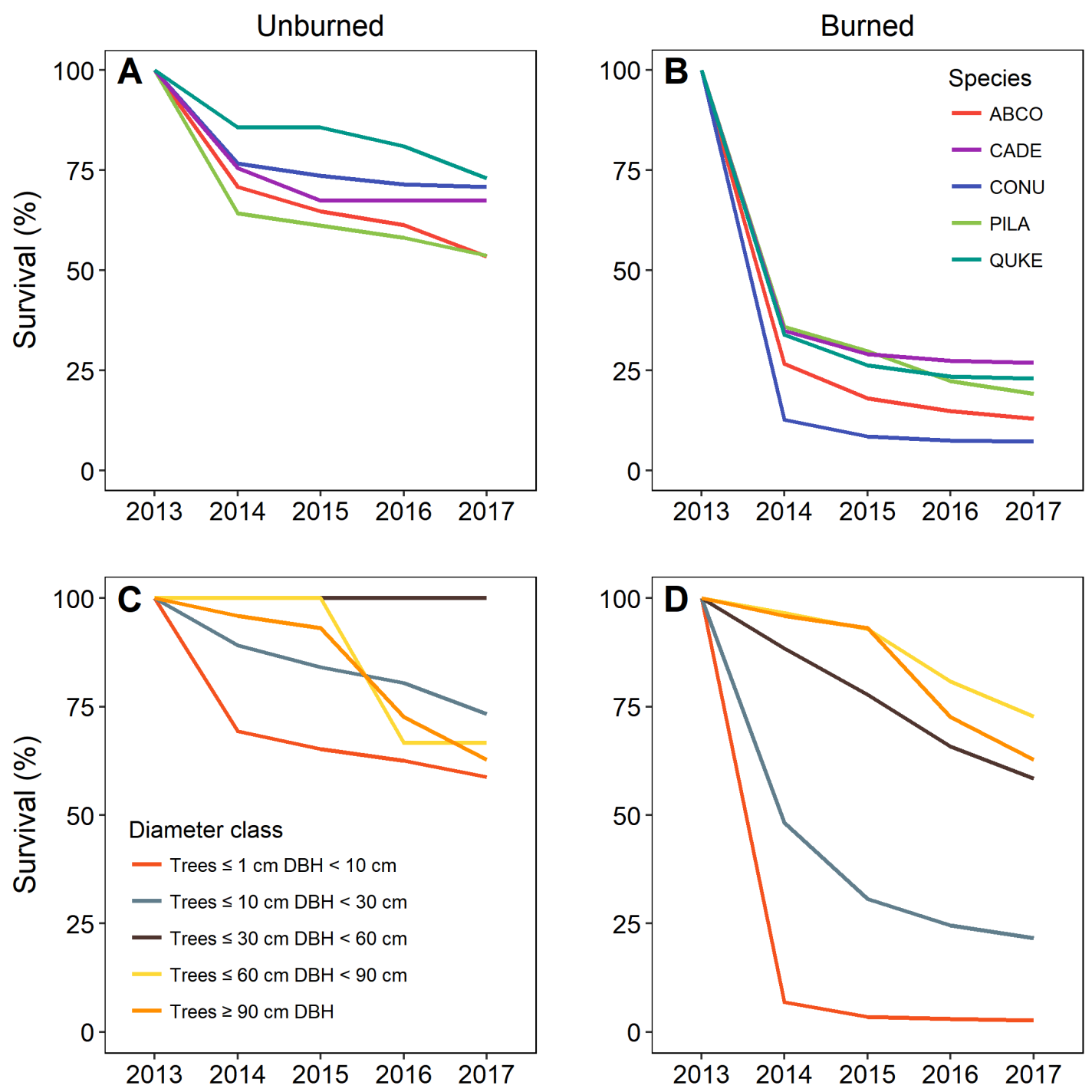

Fig. 4. Tree survival rates in the Yosemite Forest Dynamics Plot from 2014 - 2017. Trees of the five most abundant species (Abies concolor, Calocedrus decurrens, Cornus nuttallii, Pinus lambertiana, Quercus kelloggii) had higher survival rates if their boles were in unburned patches (A) compared to areas with burned substrate (B). Trees $\leq 30 \mathrm{~cm}$ DBH had higher survival rates in unburned (C) versus burned (D) patches. Survival of trees $>30 \mathrm{~cm}$ DBH did not differ between burned and unburned substrate. 

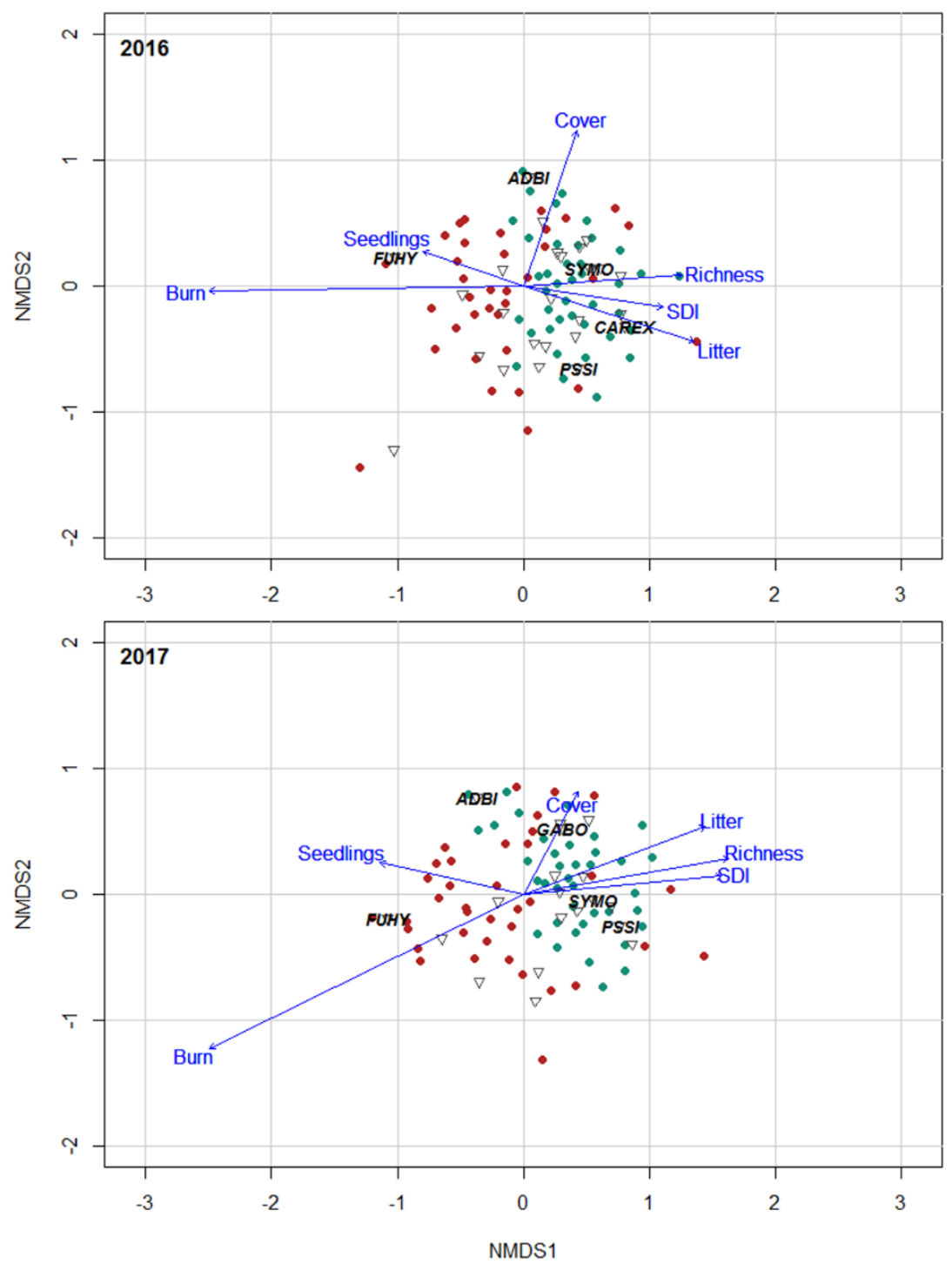

68 Fig. 5. Non-metric multidimensional scaling (NMDS) ordination showing understory vegetation 69 community differences in the Yosemite Forest Dynamics Plot (YFDP) 3 and 4 years following the 2013 Yosemite Rim fire. Vegetation was measured in $1-\mathrm{m}^{2}$ quadrats in burned (represented by red circles) and unburned (represented by green circles) areas. Species centroids are represented by black triangles, wherein the species with the 5 largest correlation coefficients are labeled. $\mathrm{ADBI}=$ Adenocaulon bicolor; $\mathrm{CAREX}=$ Carex spp.; FUHY = Funaria hygrometrica; $\mathrm{GABO}=$ Galium bolanderi $; \mathrm{PSSI}=$ Pseudostellaria sierra $; \mathrm{SYMO}=$ Symphoricarpos mollis.

75 Environmental variables with significant associations $(P \leq 0.05)$ are represented by blue arrows.

76 Burn= percent of $1-\mathrm{m}^{2}$ quadrat that burned; Cover= percent vegetative cover; Litter $=$ depth $(\mathrm{cm})$

77 of the litter layer; Richness= number of species observed at a quadrat; SDI= the Shannon

78 Diversity Index; Seedlings= seedling abundance. 


\section{Supplemental Information}

\section{$81 \quad$ Table S1.}

82 Summary statistics for environmental variables used in non-metric multidimensional scaling

83 (NMDS) ordinations and random forest models. The variables used to construct the NMDS

84 environmental matrix were measured at the 1-m scale. Vegetation cover was measured by

85 species, therefore some quadrat values exceed $100 \%$. The random forest model variables were

86 calculated at the $10-\mathrm{m}$ scale.

\begin{tabular}{|c|c|c|c|c|}
\hline & Mean & Min & Max & STD \\
\hline \multicolumn{5}{|c|}{ NMDS environmental variables (1-m scale) } \\
\hline Cover $(\%)$ & 16.5 & 0.0 & 150.8 & 22.6 \\
\hline Litter depth $(\mathrm{cm})$ & 2.1 & 0.0 & 13.0 & 2.0 \\
\hline Proportion burned (\%) & 57.6 & 0.0 & 100.0 & 48.2 \\
\hline Seedling abundance & 4.3 & 0.0 & 52.0 & 7.4 \\
\hline SDI & 0.8 & 0.0 & 2.0 & 0.7 \\
\hline Species richness & 4.9 & 1.0 & 15.0 & 3.4 \\
\hline \multicolumn{5}{|c|}{ Random forest model variables (10-m scale) } \\
\hline Basal area $\left(\mathrm{m}^{2} \mathrm{ha}^{-1}\right)$ & 84.0 & 0.0 & 774.4 & 83.1 \\
\hline Distance to water (m) & 88.4 & 0.0 & 260.7 & 64.1 \\
\hline dNBR (index) & 189.6 & 7.0 & 428.0 & 68.7 \\
\hline Mortality basal area $\left(\mathrm{m}^{2} \mathrm{ha}^{-1}\right)$ & 8.3 & 0.0 & 355.1 & 17.0 \\
\hline Mortality tree density (stems ha ${ }^{-1}$ ) & 952.2 & 0.0 & 5762.0 & 794.7 \\
\hline Proportion unburned $(\%)$ & 5.0 & 0.0 & 100.0 & 12.2 \\
\hline Roughness (index) & 7.9 & 2.5 & 21.3 & 2.3 \\
\hline Shrub cover $(\%)$ & 13.7 & 0.0 & 183.7 & 22.6 \\
\hline Shrub cover, generalist $(\%)$ & 4.8 & 0.0 & 81.0 & 11.1 \\
\hline Shrub cover, montane $(\%)$ & 6.1 & 0.0 & 95.5 & 14.3 \\
\hline Shrub cover, riparian $(\%)$ & 2.8 & 0.0 & 176.1 & 14.8 \\
\hline Slope (degrees) & 18.0 & 6.2 & 44.8 & 4.6 \\
\hline Solar incidence $\left(\mathrm{W} / \mathrm{m}^{2}\right)$ & 4512.9 & 3430.7 & 5538.3 & 287.4 \\
\hline Topographic position (index) & 0.0 & -1.5 & 2.0 & 0.3 \\
\hline Topographic ruggedness (index) & 2.4 & 0.8 & 7.4 & 0.7 \\
\hline Tree density (stems ha- $\left.{ }^{-1}\right)$ & 1514.0 & 0.0 & 7313.0 & 953.5 \\
\hline Tree density, 1 to $10 \mathrm{~cm}\left(\right.$ stems $\left.\mathrm{ha}^{-1}\right)$ & 878.6 & 0.0 & 6759.0 & 788.9 \\
\hline Tree density, 10 to $30 \mathrm{~cm}$ (stems ha ${ }^{-1}$ ) & 455.6 & 0.0 & 2327.0 & 364.1 \\
\hline Tree density, 30 to $60 \mathrm{~cm}$ (stems ha $\left.{ }^{-1}\right)$ & 109.9 & 0.0 & 886.0 & 128.4 \\
\hline Tree density, 60 to $90 \mathrm{~cm}($ stems ha-1) & 34.7 & 0.0 & 554.0 & 67.3 \\
\hline Tree density, $\geq 90 \mathrm{~cm}\left(\right.$ stems ha $\left.{ }^{-1}\right)$ & 35.5 & 0.0 & 443.0 & 63.7 \\
\hline
\end{tabular}


88 Table S2.

89 Summary of vegetation cover (by species; total can be over 100\%), mean seedling abundance per

90 quadrat, and species richness for burned and unburned understory $1-\mathrm{m}^{2}$ quadrats measured in

912016.

92

\begin{tabular}{lrrrr|rr}
\hline & \multicolumn{2}{c|}{ Early season } & \multicolumn{2}{c|}{ Late season } & \multicolumn{2}{c}{ Overall } \\
\hline & Burned & Unburned & Burned & Unburned & Burned & Unburned \\
\hline Vegetation cover (\%) & & & & & & \\
Mean & 11.8 & 21.4 & 14.5 & 22.1 & 13.1 & 21.8 \\
Min & 0 & 0 & 0 & 0 & 0 & 0 \\
Max & 112.7 & 86.8 & 150.8 & 104.5 & 150.8 & 104.5 \\
Std & 19.7 & 21.5 & 24.9 & 23.2 & 22.4 & 22.2 \\
Seedlings & & & & & & \\
$\quad$ Mean abundance & 6.1 & 2.1 & 5.8 & 2.1 & 6.0 & 2.1 \\
Species richness & & & & & & \\
Mean & 3.2 & 6.2 & 3.2 & 6.6 & 3.2 & 6.4 \\
Min & 0 & 1.0 & 0 & 0 & 0 & 0 \\
Max & 12.0 & 15.0 & 12.0 & 15.0 & 12.0 & 15.0 \\
Std & 3.1 & 3.6 & 3.1 & 3.7 & 3.1 & 3.6 \\
\hline
\end{tabular}

93 


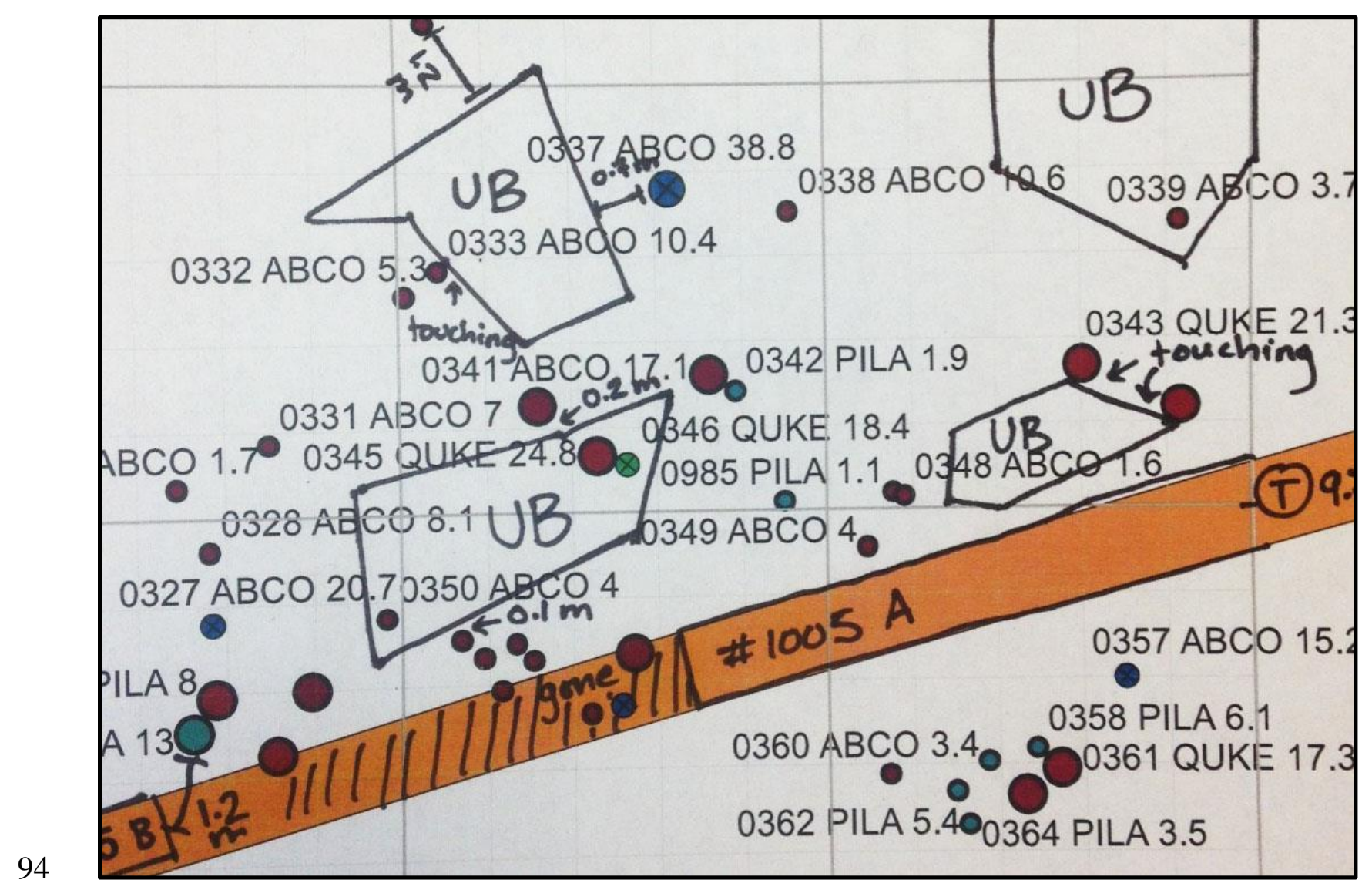

95 Figure S1. A portion of a datasheet used to map unburned patches in the Yosemite Forest

96 Dynamics Plot. Ocular estimation was used to delineate unburned patch vertices in relation to

97 features on stem map (e.g. trees, grid corners). The unburned patches were measured using meter

98 tapes and the datasheets included a 1-m grid to increase mapping accuracy. Nearby trees were

99 traversed to confirm their position as either outside, intersecting, or within an unburned patch. 


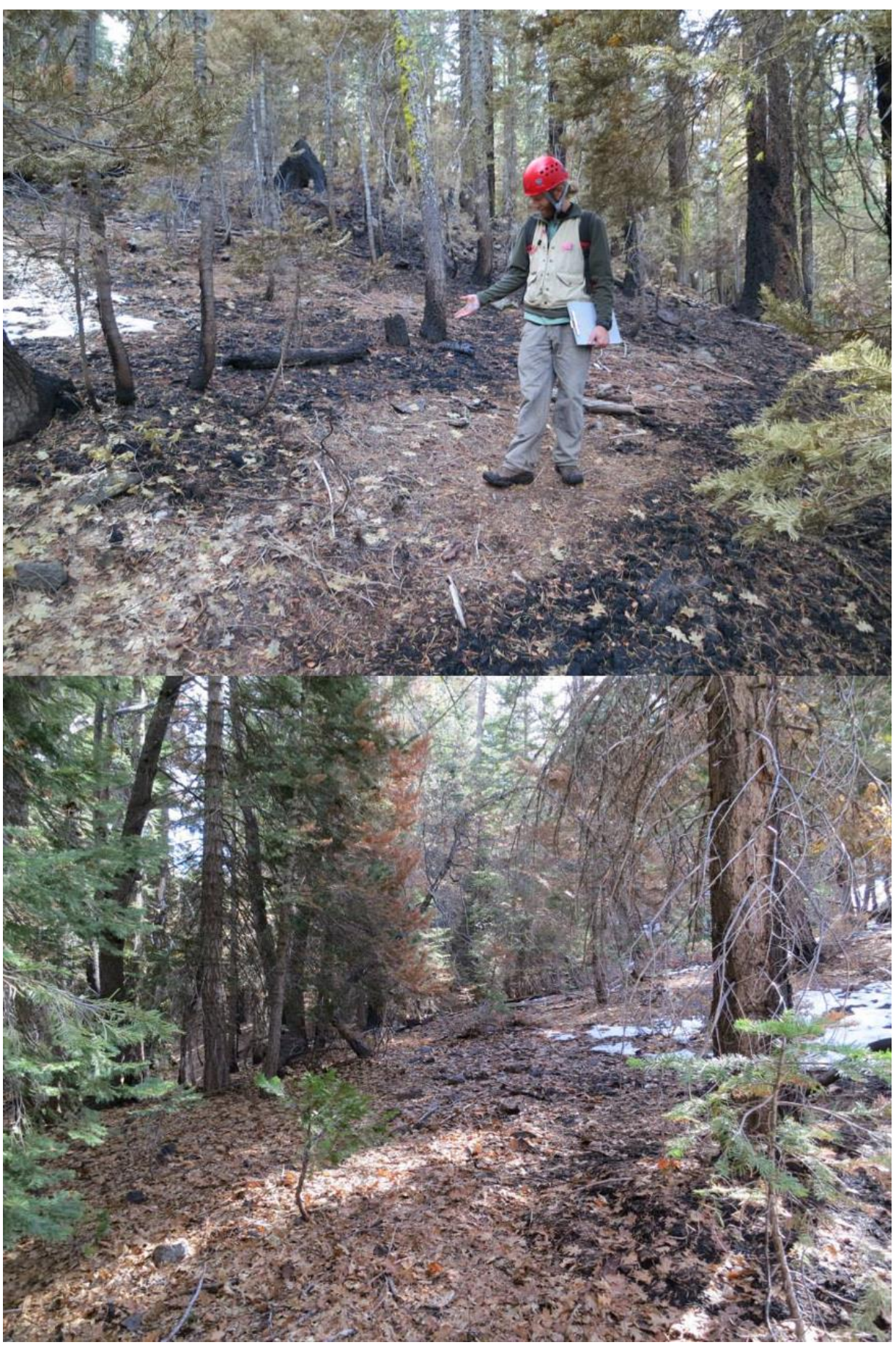
102 the Rim Fire. Unburned patches were delineated from burned areas based on the presence of ash 103 or charcoal on the forest floor or on adjacent stems, and inspection of the substrate for intact 104 litter and duff. Photo credit: James A. Lutz. 
Variable Importance
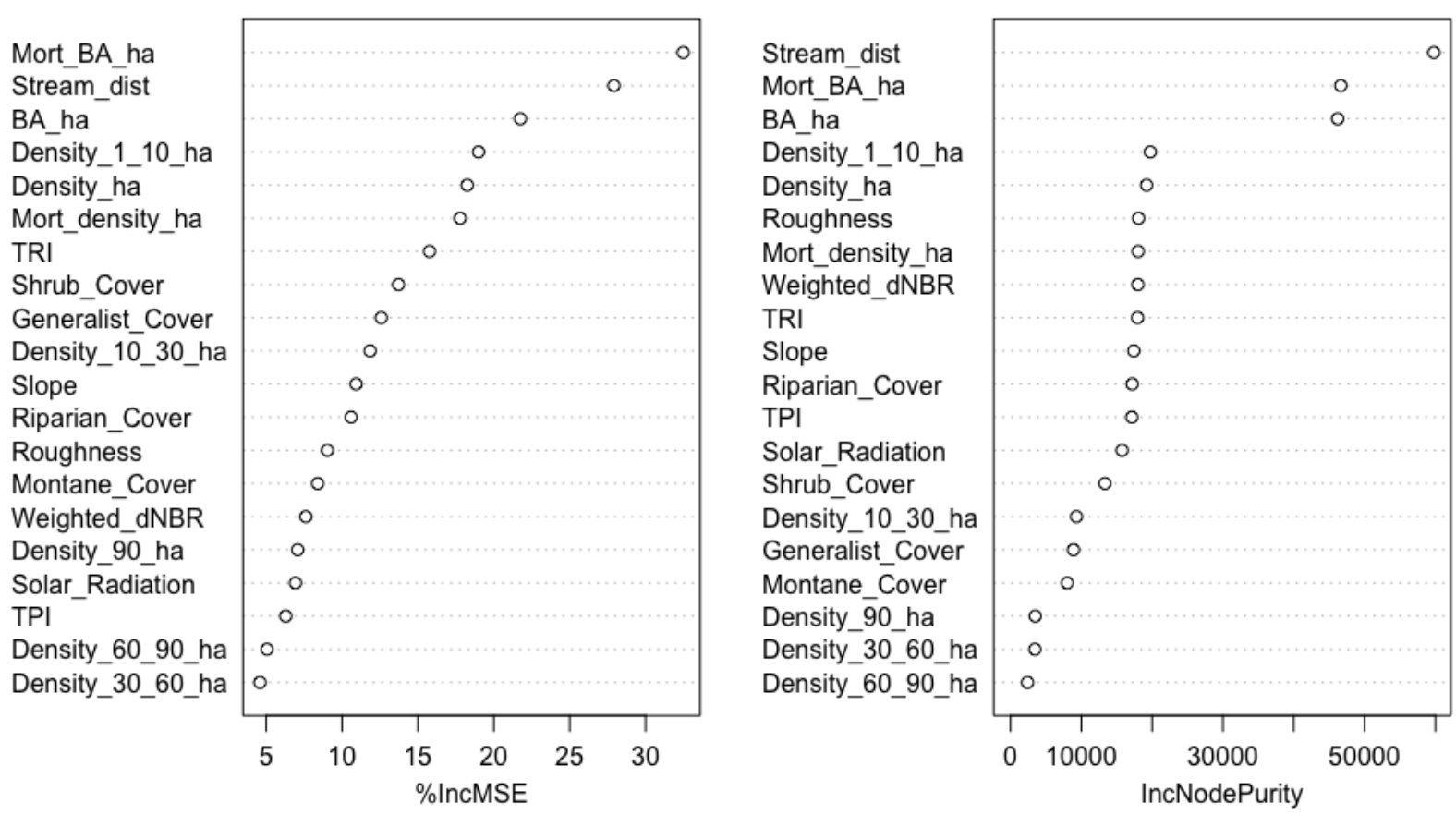

105

106

107

108

109

Figure S3. Variable importance graphs for the randomForest regression model predicting the response of proportion unburned. The metric \% IncMSE calculates the mean decrease in prediction accuracy for each variable when it is removed from the model, with larger values indicating greater variable importance. IncNodePurity is a measure by which each variable 110 contributes to higher node purities. 


\section{Variable Importance}
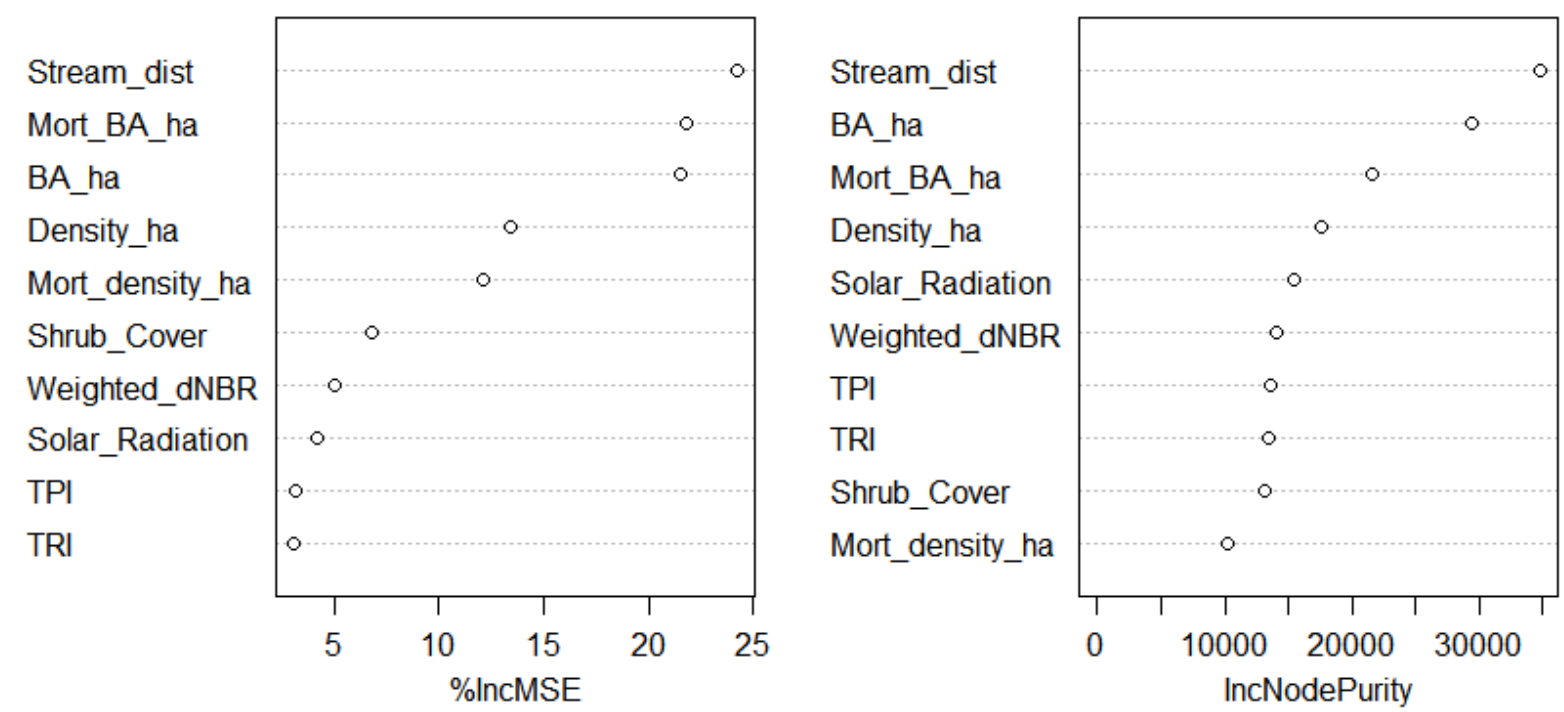

112 Figure S4. Variable importance graphs for the top 10 variables in the randomForest presence113 only model predicting the response of proportion unburned. 